\title{
Effects of Inclusion of Schizochytrium spp. and Forage-to-Concentrate Ratios on Goats' Milk Quality and Oxidative Status
}

\author{
Alexandros Mavrommatis ${ }^{1}(\mathbb{D})$, Kyriaki Sotirakoglou ${ }^{2}\left(\mathbb{D}\right.$, Charalampos Kamilaris $^{3}$ (D) and Eleni Tsiplakou ${ }^{1, *(D)}$ \\ 1 Laboratory of Nutritional Physiology and Feeding, Department of Animal Science, School of Animal \\ Biosciences, Agricultural University of Athens, Iera Odos 75, gR-11855 Athens, greece; mavrommatis@aua.gr \\ 2 Laboratory of Mathematics and Statistics, Department of Natural Resources and Agricultural Engineering, \\ School of Environment and Agricultural Engineering, Agricultural University of Athens, Iera Odos \\ 75, gR-11855 Athens, greece; sotirakoglou@aua.gr \\ 3 School of geosciences, University of Edinburgh, Drummond Street, Edinburgh EH8 9XP, UK; \\ harry.kamilaris@sruc.ac.uk \\ * Correspondence: eltsiplakou@aua.gr; Tel.: +30-21-0529-4435; Fax: +30-21-0529-4413
}

Citation: Mavrommatis, A.;

Sotirakoglou, K.; Kamilaris, C.;

Tsiplakou, E. Effects of Inclusion of

Schizochytrium spp. and

Forage-to-Concentrate Ratios

on Goats' Milk Quality and Oxidative Status. Foods 2021, 10, 1322. https:// doi.org/10.3390/foods10061322

Academic Editor: Zwi g. Weinberg

Received: 20 May 2021

Accepted: 7 June 2021

Published: 8 June 2021

Publisher's Note: MDPI stays neutral with regard to jurisdictional claims in published maps and institutional affiliations.

Copyright: (C) 2021 by the authors Licensee MDPI, Basel, Switzerland. This article is an open access article distributed under the terms and conditions of the Creative Commons Attribution (CC BY) license (https:// creativecommons.org/licenses/by/ $4.0 /)$

\begin{abstract}
Although the dietary inclusion level of polyunsaturated fatty acids (PUFA) and the forage: concentrate $(\mathrm{F}: \mathrm{C})$ ratio affect milk quality, their interaction has not been broadly studied. To address such gaps and limitations a two-phase trial using twenty-two dairy goats was carried out. During the first phase, both groups ( $20 \mathrm{HF} n=11$; high forage and $20 \mathrm{HG} n=11$; high grain) were supplemented with $20 \mathrm{~g}$ Schizochytrium spp./goat/day. The $20 \mathrm{HF}$ group consumed a diet with F:C ratio 60:40 and the $20 \mathrm{HG}$-diet consisted of F:C $=40: 60$. In the second phase, the supplementation level of Schizochytrium spp. was increased to $40 \mathrm{~g} /$ day/goat while the F:C ratio between the two groups were remained identical ( $40 \mathrm{HF} n=11$; high forage and $40 \mathrm{HG} n=11$; high grain). Neither the Schizochytrium spp. supplementation levels (20 vs. 40) nor the F:C ratio (60:40 vs. 40:60) affected milk performance. The high microalgae level $(40 \mathrm{~g})$ in combination with high grain diet $(40 \mathrm{HG})$ modified the proportions of docosahexaenoic acid (DHA), docosapentaenoic acid (DPA), and conjugated linoleic acid (CLA) and the $\omega 3 / \omega 6$ ratio in milk, to a beneficial manner according to human health recommendation guidelines. However, the highest inclusion level of Schizochytrium spp. (40 g) and foremost in combination with the high grain diets (40 HG) induced an oxidative response as observed by the increased protein carbonyls (CP) and malondialdehyde (MDA) levels in milk and blood plasma indicating severe limitations for a long-term, on-farm application. In conclusion, the supplementation with $20 \mathrm{~g}$ Schizochytrium spp. and high forage diet (60:40) appears to be an ideal formula to enrich dairy products with essential biomolecules for human health without adversely affect milk oxidative stability.
\end{abstract}

Keywords: microalgae; fatty acid; antioxidant; grains; forage; starch; MDA; DHA; TAC; rumen

\section{Introduction}

In the Western diet, the average intake of the health-beneficial $\omega 3$ long-chain polyunsaturated fatty acids (LCPUFA) such as the eicosapentaenoic acid (EPA) and docosahexaenoic acid (DHA) is below the recommended level, raising interest to enrich foods with w3 LCPUFA [1]. In this context, several feedstuffs and novel feed additives enriched with bioactive fatty acids have been tested in ruminant nutrition aiming to alter milk fatty acid profile [2]. Amongst these efforts, the inclusion of microalgae in animals' diets appears to be the most sustainable and vegetable-friendly strategy to improve polyunsaturated fatty acid (PUFA) milk content [3-8]. More specifically, Schizochytrium spp., a unicellular eukaryote belonging to Thraustochytriaceae family, appears to be a genus that walks the line between marine fungi and microalgae, exploiting the structure and properties of both kingdoms. Its heterotrophic cultivation depicts a promising perspective since it is feasible 
to produce highly valuable nutrients by utilizing low-cost substrates such as organic wastes without the dependence on sunlight [9]. Notably, the supplementation with 20,40, and $60 \mathrm{~g}$ Schizochytrium spp./day in goats' diet increased milk docosapentaenoic acid (DPA), DHA, and conjugated linoleic acid (CLA) content, and $\omega 3 / \omega 6$ ratio [7]. However, high inclusion levels of Schizochytrium spp. in goats' diet with a moderate forage to concentrate $(\mathrm{F}: \mathrm{C}=50: 50)$, ratio reduced the abundance of cellulolytic microbes and caused milk fat depression [10,11].

The F:C ratio, is also a keystone factor that alters rumen fermentation and milk chemical composition [12]. A decrease in milk fat and PUFA content was found, when the crushed linseeds- (rich in PUFA) fed cows shifted from high to a low forage diet [13]. Although a meta-analysis study in cows pointed out that marine oils compared to linseeds cause a sharp decrease in their milk fat content [14], we speculated that alterations in the $F: C$ ratio with various inclusions levels of PUFA-rich microalgae simultaneously, could further modulate goats milk composition and fatty acid profile.

However, the high propensity of PUFA to oxidation could severely affect animals and products oxidative balance as well [15]. Notably, the inclusion of 40 and $60 \mathrm{~g}$ Schizochytrium spp./day in goats' diet induced a cascade of pro-oxidant incidences in both blood and milk resulting in a compromised oxidative status [16]. Furthermore, changes in the F:C ratio could regulate ruminants' oxidative status as well. Interestingly, in goats, a high grain diet increased the lipopolysaccharides (LPS) level in their ruminal fluid, resulting in a low-grade pro-inflammatory response and oxidative stress [17]. Specifically, the mRNA levels and activities of glutathione peroxidase (GSH-Px), catalase (CAT), and superoxide dismutase (SOD) were decreased in goat's liver, while malondialdehyde (MDA) concentration was upsurged [17]. Additionally, the high starch level increases the degradation of exogenous antioxidants compounds such as vitamins A, E, and the carotenoids within the rumen resulting in a lower antioxidant ability of the organism $[18,19]$.

Even though both lipids supplementation and F:C ratio alterations portray welldocumented dietary interventions in ruminants, scarce information exists about their interactions on milk composition and its oxidative stability. Taking into consideration the aforementioned and our preliminary results from previous trials on Schizochytrium spp. in goats diet $[7,10,11,16]$, the objective of this study was to evaluate the impact of two inclusion levels of Schizochytrium spp. (20 g and $40 \mathrm{~g} /$ day) and two forage to concentrate ratios (60/40 and 40/60) (a) on milk performance and chemical composition, (b) on the fatty acid profile of blood plasma and milk, and on (b) gSH-Px, CAT, SOD, glutathione reductase (GR), glutathione transferase (GST) activities in blood plasma and SOD, gR, CAT, and lactoperoxidase (LPO) activities in milk and (c) total antioxidant capacity and oxidative stress indicators (MDA and protein carbonyls (PCs) in both blood plasma and milk of dairy goats.

\section{Materials and Methods}

\subsection{Diets and Experimental Design}

The study was conducted with respect to the guidelines of the European Union Directive on the defense of animals used for scientific purposes (EU 63/2010; Council of the European Union 2010). Twenty-two crossbred dairy goats (Alpine $\times$ Local (Greek) breeds) at early lactation (70 \pm 10 days in milk), were separated into two homogenous groups ( $n=11$ per group) according to their age (3-4 years old), body weight (BW; $50.6 \pm 6.1 \mathrm{~kg})$, and (4 fat corrected \%) milk yield $\left(\mathrm{FCM}_{4} \%\right)$. The experimental trial was divided into two phases (two dietary groups each), which lasted 8 weeks each, with the first 2 weeks being an adaptation period. During the first phase, each goat of both groups $(20 \mathrm{HF}$; high forage and $20 \mathrm{HG}$; high grain) was supplemented with $20 \mathrm{~g}$ Schizochytrium spp./day. The F:C ratio of the $20 \mathrm{HF}$ group was $60 \%$ forages (alfalfa hay and wheat straw) and $40 \%$ concentrate while that of $20 \mathrm{HG}$ was $40 \%$ forages (alfalfa hay and wheat straw) and $60 \%$ concentrates (Table 1). In the second phase, the supplementation level of Schizochytrium spp. was increased to $40 \mathrm{~g} /$ day/goat while the $\mathrm{F}: \mathrm{C}$ ratio between the two groups were remained 
identical (40 HF; high forage and $40 \mathrm{HG}$; high grain) (Table 1). Schizochytrium spp. is a commercial product traded as DHAgold by the DSM feed industry (DSM Nutritional Products, Marousi, greece). The Schizochytrium spp. were added into concentrate mix aiming to provide 20 and $40 \mathrm{~g} /$ goat/day in both high forage $(1 \mathrm{Kg}$ concentrate/goat/day; $20 \mathrm{~g} /$ Schizochytrium spp./Kg in $20 \mathrm{HF}$ and $40 \mathrm{~g} /$ Schizochytrium spp./Kg in $40 \mathrm{HF}$ ) and high grain $(1.3 \mathrm{Kg}$ concentrate/goat/day; $15.4 \mathrm{~g} /$ Schizochytrium spp./Kg in $20 \mathrm{HF}$ and $30.7 \mathrm{~g} /$ Schizochytrium spp./Kg in $40 \mathrm{HF}$ ) diets (Table 1; Table S1). The rations were designed to be isocaloric and isonitrogenous (Table 1; Table S1). The alfalfa hay, wheat straw and concentrates samples were analyzed for organic matter (OM; Official Method 7.009), dry matter (DM; Official Method 7.007), and crude protein (CP; Official Method 7.016) according to the Association of Official Analytical Chemists (1984) using a Kjeldahl Distillation System (FOSS Kjeltec 8400, Demark). Neutral detergent fiber (NDF) and acid detergent fiber (ADF) expressed exclusive of residual ash according to the method of Van Soest using an ANKOM 2000 Fiber Analyzer (New York, NY, USA) as described by Tsiplakou et al. [20] (Table S2). Non-fibrous carbohydrates were calculated based on the equation described by Cannas et al., [21]. Feed samples were also analyzed for fatty acids profile according to the method of O'Fallon et al., [22] (Table 2). The forages (alfalfa hay and wheat straw) were provided separately from the concentrates. Animals were fed on a group basis, considering their average energy and nutritional requirements in order for the experimental design to represent the typical commercial farm feeding management and the results having practical implications for small ruminants. The available feeding space was higher than the one recommended for adult housed goats $(0.33 \mathrm{~m}$ per animal) considering to favor simultaneous access and lower competitive interactions at the feeder among animals. Forage was provided with the concentrate in two equal portions after milking. Diet consumption was being recorded on daily basis.

Table 1. Ration components ( $\mathrm{Kg} /$ goat/day) and chemical composition (g/day) of the diets were administered to the four groups (20 HF, $20 \mathrm{HG}, 40 \mathrm{HF}$, and $40 \mathrm{HG}$ ) of goats involved in the trials.

\begin{tabular}{|c|c|c|c|c|}
\hline & \multicolumn{4}{|c|}{ Treatment } \\
\hline & $20 \mathrm{HF}$ & $20 \mathrm{HG}$ & $40 \mathrm{HF}$ & $40 \mathrm{HG}$ \\
\hline \multicolumn{5}{|l|}{ Diet components (Kg per goat) } \\
\hline Alfalfa hay & 1.2 & 0.7 & 1.2 & 0.7 \\
\hline Wheat straw & 0.3 & 0.18 & 0.3 & 0.18 \\
\hline Concentrate mix & 1 & 1.3 & 1 & 1.3 \\
\hline Schizochytrium spp. (g) & 20 & 20 & 40 & 40 \\
\hline Forage to Concentrate $(\mathrm{F}: \mathrm{C})$ ratio & $1.5: 1(60: 40)$ & $0.88: 1.3(40: 60)$ & $1.5: 1(60: 40)$ & $0.88: 1.3(40: 60)$ \\
\hline Dry Matter & 2282 & 1989 & 2298 & 2000 \\
\hline Ash & 188 & 144 & 192 & 142 \\
\hline Crude Protein & 312 & 311 & 312 & 311 \\
\hline Ether Extract & 82.3 & 87.9 & 90.3 & 97.0 \\
\hline Ash-free NDF treated with amylase & 932 & 712 & 931 & 710 \\
\hline Acid Detergent Fiber & 608 & 399 & 605 & 409 \\
\hline Non Fibrous Carbohydrate & 987 & 925 & 976 & 920 \\
\hline Starch & 474 & 542 & 462 & 542 \\
\hline NDF/Starch & 2.0 & 1.3 & 2.0 & 1.3 \\
\hline
\end{tabular}

20 HF: 20 g Schizochytrium spp. and high forage diet (60:40); 20 HG: $20 \mathrm{~g}$ Schizochytrium spp. and high grain diet (40:60); 40 HF: $40 \mathrm{~g}$ Schizochytrium spp. and high forage diet (60:40); 40 HG: $40 \mathrm{~g}$ Schizochytrium spp. and high grain diet (40:60). 
Table 2. Alfalfa hay, wheat straw and concentrates fatty acid profile (FA) (\% of total FA).

\begin{tabular}{|c|c|c|c|c|c|c|}
\hline \multirow[t]{2}{*}{ Fatty Acid } & \multicolumn{4}{|c|}{ Concentrates } & \multicolumn{2}{|c|}{ Forages } \\
\hline & $20 \mathrm{HF}$ & $20 \mathrm{HG}$ & $40 \mathrm{HF}$ & $40 \mathrm{HG}$ & Alfalfa Hay & Wheat Straw \\
\hline Myristic acid $\left(\mathrm{C}_{14: 0}\right)$ & 2.48 & 2.12 & 3.1 & 3.18 & 6.2 & 0 \\
\hline Palmitic acid $\left(\mathrm{C}_{16: 0}\right)$ & 21.94 & 22.99 & 20.22 & 23.77 & 36.77 & 29.88 \\
\hline Stearic acid $\left(\mathrm{C}_{18: 0}\right)$ & 1.92 & 2.06 & 1.55 & 1.87 & 2.33 & 4.86 \\
\hline Oleic acid $\left(\mathrm{C}_{18: 1 \text { cis-9 }}\right)$ & 28.95 & 31.83 & 22.13 & 27.08 & 2.49 & 34.77 \\
\hline Linoleic acid $\left(C_{18: 2 n-6 \text { cis }}\right)$ & 31.96 & 31.04 & 31.09 & 27.76 & 18.27 & 21.95 \\
\hline Eicosanoic acid $\left(\mathrm{C}_{20: 0}\right)$ & 0.22 & 0.23 & 0.17 & 0.2 & 0.64 & 0.82 \\
\hline Linolenic acid $\left(\mathrm{C}_{18: 3 \mathrm{n}-3}\right)$ & 1.07 & 0.96 & 1.13 & 0.88 & 30.68 & 1.86 \\
\hline Eicosatrienoic acid $\left(\mathrm{C}_{20: 3 \mathrm{n} 3}\right)$ & 0.44 & 0.37 & 0.56 & 0.47 & 1.5 & 1.37 \\
\hline Lignoceric acid $\left(\mathrm{C}_{24: 0}\right)$ & 0.32 & 0.25 & 0.26 & 0.25 & 0 & 0.73 \\
\hline Docosapentaenoic acid $\left(C_{22: 5 n-6}\right)$ & 2.42 & 1.92 & 4.7 & 3.78 & 0 & 0 \\
\hline Docosahexaenoic acid $\left(C_{22: 6 n-3}\right)$ & 6.71 & 5.25 & 13.76 & 10.21 & 0 & 0 \\
\hline
\end{tabular}

20 HF: 20 g Schizochytrium spp. and high forage diet (60:40); 20 HG: 20 g Schizochytrium spp. and high grain diet (40:60); 40 HF: 40 g Schizochytrium spp. and high forage diet (60:40); 40 HG: $40 \mathrm{~g}$ Schizochytrium spp. and high grain diet (40:60).

\subsection{Sample Collection}

The goats were milked two times per day (08:00 and 17:00) with a milking machine. Individual milk samples $(n=264 ; 11$ goats/group $\times 4$ groups $(2$ experimental phases of 2 dietary groups each) $\times 6$ sampling times) were collected on the 7th, 14th, 21th, 28th, 35 th, and 42nd experimental day of each experimental phase and used for milk chemical composition. While milk samples obtained from 21th and 42nd experimental days $(n=88$; 11 goats/group $\times 4$ groups $\times 2$ sampling times) of each experimental phase were used for fatty acid profile and oxidative status analyses. Milk yield was recorded at the same experimental days (7th, 14th, 21st, 28th, 35th, and 42nd) taking into account the two milked quantities, while each of the aforementioned individual milk samples was performed by the mixture of $5 \%$ of the milk volume obtained by the two milkings aiming to ensure the highest reliability.

Individual blood samples $(n=88)$ were also taken on the 21st and 42nd experimental days (of each experimental phase) from the jugular vein of each goat after the milking prior to access on feeds. Approximately, $10 \mathrm{~mL}$ of whole blood were immediately transferred to heparin-containing tubes (170 units heparin; BD Vacutainer, Plymouth, UK) and stored in an icebox (Thomas Scientific, Swedesboro, NJ, USA) until their transfer to the Laboratory of Nutritional Physiology and Feeding. Then, the blood samples were centrifuged (SL16R, Thermo Fisher Scientific, Waltham, MA, USA) at $2500 \mathrm{rpm}$ for $15 \mathrm{~min}$ at $4{ }^{\circ} \mathrm{C}$ to separate plasma from the cells.

Milk samples for chemical composition were analyzed on the collection day, while milk and blood plasma samples were stored at $-80^{\circ} \mathrm{C}$, prior to fatty acids and oxidative status analyses.

\subsection{Milk Chemical Composition}

Chemical composition (fat, protein, and lactose) was analyzed using an IR spectrometer (MilkoScan 133; FOSS, Hillerød, Demark) after proper validation by Kjeldahl [23] and gerber [24] methods. Fat corrected- $\left(\mathrm{FCM}_{4} \%\right)$ and energy corrected- (ECM) milk yield was calculated using the following formulas:

Fat corrected milk (FCM) in $4 \%$ based on the Equation (1)

$$
\mathrm{FCM}_{4 \%}=(0.40+0.15 \times \mathrm{F}) \times \mathrm{M}
$$

where $\mathrm{F}=$ fat content $(\%)$ and $\mathrm{M}=$ milk yield in $\mathrm{kg}$ [3] .

Energy corrected milk (ECM) yield based on the Equation (2)

$$
\mathrm{ECM}=(\text { milk yield } \times 0.327)+(\text { fat yield } \times 12.95)+(\text { protein yield } \times 7.2)
$$




\subsection{Milk and Blood Fatty Acid Analysis}

The plasma fatty acid analysis was carried out with the method of Bondia-Pons et al. [25] as previously described by Tsiplakou et al. [26]. Milk samples were analyzed for fatty acid according to the method of Nourooz-Zadeh and Appelqvist [27] as described by Tsiplakou et al. [28]. FA profile was performed using an Agilent $6890 \mathrm{~N}$ gas chromatograph equipped with an HP-88 capillary column $(60 \mathrm{~m} \times 0.25 \mathrm{~mm}$ i.d. with $0.20 \mu \mathrm{m}$ film thickness, Agilent). Information about the temperature program and standard used are available by Mavrommatis and Tsiplakou [7]. The groups of FA were defined as follow:

Short-Chain Saturated Fatty Acids (SCFA) $=\mathrm{C}_{6: 0}+\mathrm{C}_{8: 0}+\mathrm{C}_{10: 0}+\mathrm{C}_{11: 0}$,

Medium-Chain Saturated Fatty Acids (MCFA) $=C_{12: 0}+C_{13: 0}+C_{14: 0}+C_{15: 0}+C_{16: 0}$,

Long-Chain Saturated Fatty Acids (LCFA) $=\mathrm{C}_{17: 0}+\mathrm{C}_{18: 0}+\mathrm{C}_{20: 0}$,

Mono-Unsaturated Fatty Acids (MUFA) $=C_{14: 1}+C_{15: 1}+C_{16: 1}+C_{17: 1}+{ }_{\text {cis-9 }} C_{18: 1}+$ trans-11 $C_{18: 1}+$ trans $C_{18: 1}$,

Poly-Unsaturated Fatty Acids (PUFA) $={ }_{\text {cis-9, }}$, trans-11 $C_{18: 2}+C_{18: 2 n-6 c}+C_{18: 2 n-6 t}+C_{18: 3 n-3}+C_{18: 3 n-6}+C_{20: 3 n-3}$,

Saturated Fatty Acids (SFA) $=$ SCFA + MCFA + LCFA,

Unsaturated Fatty Acids (UFA) = PUFA + MUFA,

Saturated/Unsaturated $(\mathrm{S} / \mathrm{U})=(\mathrm{SCFA}+\mathrm{MCFA}+\mathrm{LCFA}) /(\mathrm{PUFA}+\mathrm{MUFA})$,

Atherogenic index $(\mathrm{AI})=\left(\mathrm{C}_{12: 0}+4 \times \mathrm{C}_{14: 0}+\mathrm{C}_{16: 0}\right) /(\mathrm{PUFA}+\mathrm{MUFA})$,

Thrombogenic index $(\mathrm{TI})=\left(\mathrm{C}_{14: 0}+\mathrm{C}_{16: 0}+\mathrm{C}_{18: 0}\right) /(0.5 \times$ MUFA $)+(0.5 \times \mathrm{n}-6$ PUFA $)+(3 \times \omega 3$ PUFA $)$

$$
+(\omega 3 \text { PUFA/ } \omega 6 \text { PUFA), }
$$

Health promoting index $(\mathrm{HPI})=(\omega 6 \mathrm{PUFA}+\omega 3 \mathrm{PUFA}+\mathrm{MUFA}) /\left(\mathrm{C}_{12: 0}+4 \times \mathrm{C}_{14: 0}+\mathrm{C}_{16: 0}\right)$.

\subsection{Antioxidant Enzymes Activities and Oxidative Status Indicators}

The assays for antioxidant enzyme activities, oxidative stress indicators, and the total antioxidant capacity were performed using a UV/Vis spectrophotometer (GENESYS 180, Thermo Fisher Scientific, Waltham, MA, USA) as previously described [29]. The gSTs activities were recorded by monitoring the conjunction of gSH to 1-chloro-2,4-dinitrobenzene (CDNT) at $340 \mathrm{~nm}$. CAT activity was performed using a commercial spectrophotometric kit (Catalase Assay Kit; CAT100, Sigma-Aldrich, St. Louis, MO, USA). gSH-Px activity was assayed according to Paglia and Valentine [30]. gR activity was performed by measuring the reduction of oxidized glutathione (GSSG) to reduce glutathione in presence of nicotinamide adenine dinucleotide phosphate (NADPH) at $340 \mathrm{~nm}$. SOD activity was recorded by monitoring the inhibition of cytochrome coxidation at $550 \mathrm{~nm}$. LPO activity in milk was performed by monitoring the oxidation of 2,2'-Azino-bis (3-ethylbenzthiazoline-6-sulfonic acid) ABTS in presence of hydrogen peroxide at $340 \mathrm{~nm}$. MDA was measured according to Nielsen et al. [31] with some modifications described by Mavrommatis et al. [32]. The protein carbonyls (PC) were assayed according to the method of Patsoukis et al. [33]. The ABTS [34,35] and the ferric reducing ability of plasma (FRAP) [36] assays were used to assess the total antioxidant capacity.

\subsection{Statistics}

Dataset was evaluated in SPSS.IBM software (v 20.0) and the results are depicted as mean \pm standard error of means (SEM). The milk yield and body weight of each experimental phase were analyzed separately to avoid the effect of the lactation stage. The effect of dietary treatment between two groups in both experimental phases was assessed by performing a gLM for repeated measures analysis of variance. The dietary treatments (D) (D = $20 \mathrm{HF}$ and $20 \mathrm{HG}$ for phase 1 and $40 \mathrm{HF}$ and $40 \mathrm{HG}$ for phase 2) were defined as 
the fixed factor and the sampling time (S) as the repeated measure, while their interactions $(\mathrm{D} \times \mathrm{S})$ were also assessed, according to the following model:

$$
Y_{i j k l}=\mu+D_{i}+S_{j}+A_{k}+(D \times S)_{i j}+e_{i j k l}
$$

where is $Y_{i j k l}$ the dependent variable, $\mu$ the overall mean, $D_{i}$ the effect of dietary treatment ( $i=2 ; 20 \mathrm{HF}$ and $20 \mathrm{HG}$ for phase 1 and $40 \mathrm{HF}$ and $40 \mathrm{HG}$ for phase 2$), S_{j}$ the effect of sampling time ( $j=6 ; 7$ th, 14 th, 21st, 28 th, 35th, and 42 nd experimental day), $A_{k}$ the animal's random effect, $(D \times S)_{i j}$ the interaction between dietary treatments and sampling time, and $e_{i j k l}$ the residual errors. A total of 132 observations (11 goats $\times 2$ dietary groups $\times 6$ sampling times) were emerged for each experimental phase. Posthoc analysis was applied when appropriate using Tukey's multiple range test. For all tests, the significance level was set at $p=0.05$. Simplifying the visualization of these results, graphPad Prism 6.0 (2012) depicted interleaved bars (Figures 1 and 2 and Figure S1A,B).

Discriminant analyses were also performed (variables were entered independent together) on fatty acids and oxidative status pooled data (both in blood plasma (A) and milk (B)) to establish those variables capable of distinguishing and classifying samples amongst the four dietary groups ( $20 \mathrm{HF}, 20 \mathrm{HG}, 40 \mathrm{HF}$, and $40 \mathrm{HG})$. Wilk's lambda $(\lambda)$ criterion was used for assessing discriminant functions [37]. Sixteen and forty-seven variables for blood and milk fatty acid profile and nine and six for blood plasma and milk oxidative status were entered to create four models to distinguish the eighty-eight samples of each case (4 groups $\times 11$ goats/group $\times 2$ sampling time). Moreover, Pearson correlations were performed on milk fatty acid profile aiming to unveil significant correlations between individual fatty acids.
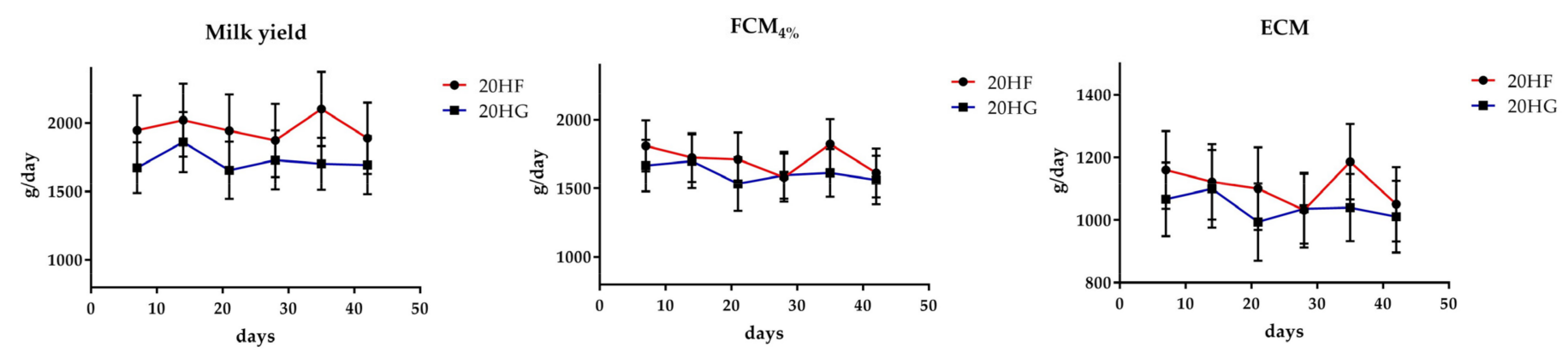

Milk fat content
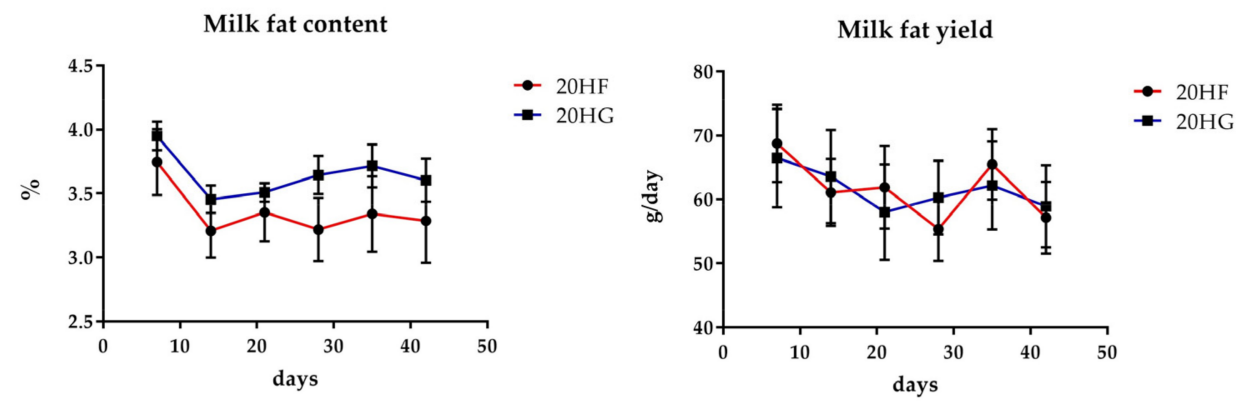

Figure 1. Mean milk performance of goats fed diets with $20 \mathrm{~g}$ Schizochytrium spp. and two different forage to concentrate ratios (20 HF; red line and $20 \mathrm{HG}$; blue line) throughout the experimental period. Error bars represent the standard error of the means (SEM). 20 HF: $20 \mathrm{~g}$ Schizochytrium spp. and high forage diet (60:40); $20 \mathrm{HG}: 20 \mathrm{~g}$ Schizochytrium spp. and high grain diet (40:60). 


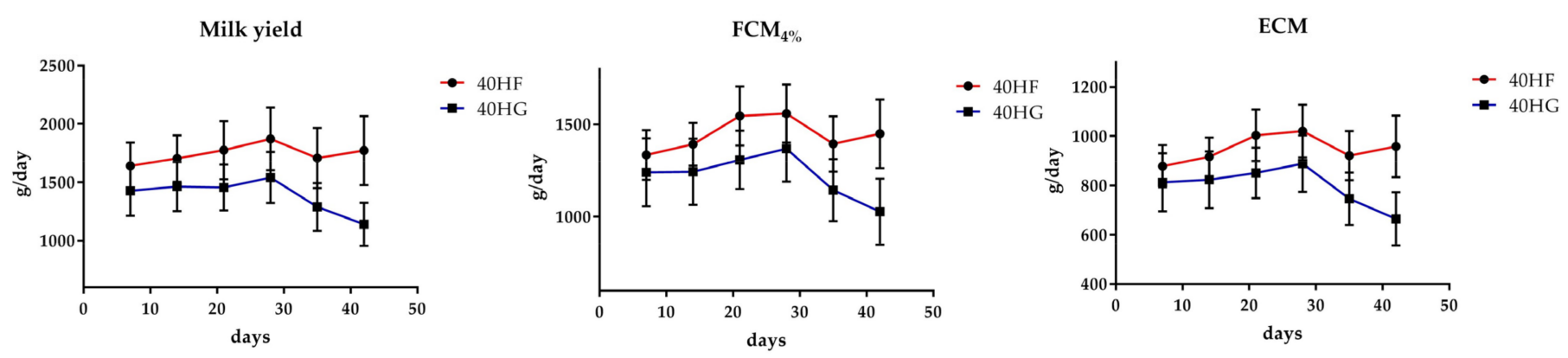

Milk fat content
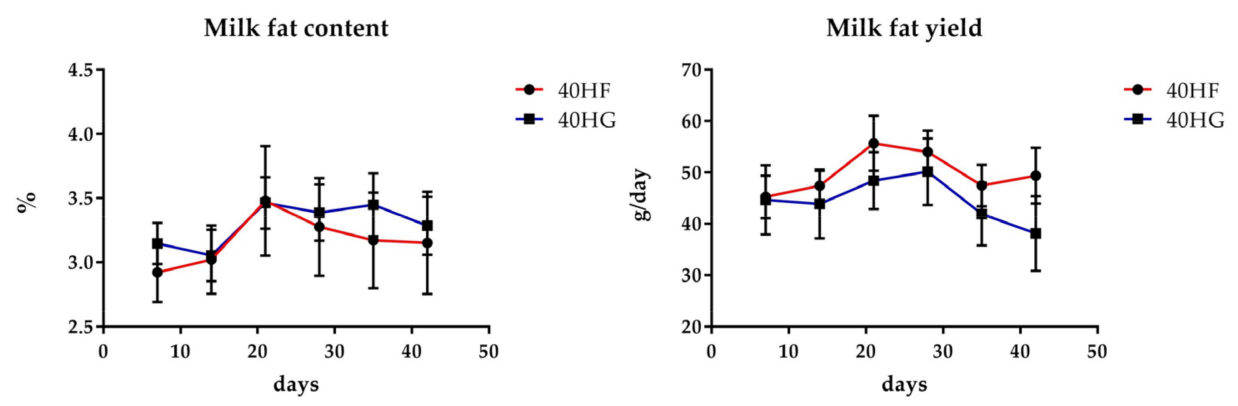

Figure 2. Mean milk performance of goats fed diets with $40 \mathrm{~g}$ Schizochytrium spp. and two different forage to concentrate ratios (40 HF; red line and $40 \mathrm{HG}$; blue line) throughout the experimental period. Error bars represent the standard error of the means (SEM). 40 HF: 40 g Schizochytrium spp. and high forage diet (60:40); 40 HG: 40 g Schizochytrium spp. and high grain diet (40:60).

Blood and milk fatty acid profiles and oxidative status of blood plasma and milk were analyzed using a gLM for three-way repeated-measures ANOVA, considering the forage to concentrate ratio $(\mathrm{F} / \mathrm{C})(60 / 40,40 / 60)$ as the between-subjects factor and microalgae level (A) (20 g, $40 \mathrm{~g})$ and sampling time (S) (21st, 42nd experimental day) as within-subjects factors and the interactions among them according to the model:

$$
Y_{i j k l m}=\mu+(F / C)_{i}+A_{j}+S_{k}+g_{l}+(F / C \times A)_{i j}+(F / C \times S)_{i k}+(A \times S)_{j k}+(F / C \times A \times S)_{i j k}+e_{i j k l m}
$$

where $Y_{i j k l m}$ is the dependent variable, $\mu$ the overall mean, $(F / C)_{i}$ the effect of forage to concentrate ratio $\left(i=2 ; 60 / 40\right.$ and 40/60), $A_{j}$ the effect of microalgae level $(j=2$; $20 \mathrm{~g}$ and $40 \mathrm{~g}), S_{k}\left(k=2 ; 21\right.$ st and 42 nd experimental day), $G_{l}$ the animal's random effect, $(F / C \times A)_{i j},(F / C \times S)_{i k},(A \times S)_{j k},(F / C \times A \times S)_{i j k}$ the two-way and three-way interactions between the aforementioned factors of the experiment and $e_{i j k l m}$ the residual errors. Posthoc analysis was applied when appropriate using Tukey's multiple range test. For all tests, the significance level was set at $p=0.05$.

\section{Results}

\subsection{Feed Intake and Body Weight}

The mean wheat straw intake was decreased by $34 \%$ and $50 \%$ in the $20 \mathrm{HF}$ and $40 \mathrm{HF}$ groups respectively (Table 3). The mean concentrate intake was also decreased in both $40 \mathrm{HF}$ and $40 \mathrm{HG}$ groups by $16 \%$. These changes also decreased the microalgae intake since they have been supplemented into the concentrates ( $40 \mathrm{HF} ; 33.7 \mathrm{~g}$ and $40 \mathrm{HG} ; 33.2 \mathrm{~g}$ vs. the planned of $40 \mathrm{~g}$; Table 3). However, the planned F:C ratios and NDF to starch proportion were not considerably modified (Table 3 ). The mean body weight (BW) of goats did not differ among the dietary groups in both experimental phases (Figure S1A,B, Tables S3 and S4). 
Table 3. Feed intake on a fresh matter basis ( $\mathrm{Kg} /$ goat and percentage of the consumed quantities compared to given) and nutrients consumption (g) of the four groups ( $20 \mathrm{HF}, 20 \mathrm{HG}, 40 \mathrm{HF}$, and $40 \mathrm{HG}$ ) of goats involved in the trials.

\begin{tabular}{|c|c|c|c|c|}
\hline & \multicolumn{4}{|c|}{ Treatment } \\
\hline & $20 \mathrm{HF}$ & $20 \mathrm{HG}$ & $40 \mathrm{HF}$ & $40 \mathrm{HG}$ \\
\hline \multicolumn{5}{|c|}{ Diet Consumption } \\
\hline Alfalfa hay & $1.2(100)$ & $0.7(100)$ & $1.2(100)$ & $0.7(100)$ \\
\hline Wheat straw & $0.2(66)$ & $0.18(99)$ & $0.15(50)$ & $0.16(90)$ \\
\hline Concentrate mix & $0.97(97)$ & $1.29(99)$ & $0.84(84)$ & $1.09(84)$ \\
\hline Schizochytrium spp.g & $19.3(97)$ & $19.8(99)$ & $33.7(84)$ & $33.2(83)$ \\
\hline Schizochytrium spp. \% of DMI & 0.89 & 1 & 1.68 & 1.86 \\
\hline Forage to Concentrate $(\mathrm{F}: \mathrm{C})$ ratio & 1.4:0.97 (59:41) & $0.88: 1.29(40: 60)$ & $1.35: 0.84(61: 39)$ & $0.76: 1.09(41: 59)$ \\
\hline \multicolumn{5}{|c|}{ Nutrients Intake } \\
\hline Dry Matter & 2161 & 1980 & 2010 & 1788 \\
\hline Ash & 179 & 144 & 173 & 131 \\
\hline Crude Protein & 305 & 309 & 286 & 276 \\
\hline Ether Extract & 79 & 87 & 76 & 83 \\
\hline Ash-free NDF amylase treated & 853 & 709 & 788 & 649 \\
\hline Acid Detergent Fiber & 555 & 398 & 515 & 383 \\
\hline Non Fibrous Carbohydrate & 954 & 920 & 866 & 810 \\
\hline Starch & 460 & 538 & 393 & 459 \\
\hline NDF/Starch & 1.9 & 1.3 & 2.0 & 1.4 \\
\hline
\end{tabular}

20 HF: 20 g Schizochytrium spp. and high forage diet (60:40); 20 HG: 20 g Schizochytrium spp. and high grain diet (40:60); 40 HF: 40 g Schizochytrium spp. and high forage diet (60:40); 40 HG: $40 \mathrm{~g}$ Schizochytrium spp. and high grain diet (40:60).

\subsection{Milk Performance and Chemical Composition}

In Figures 1 and 2 are depicted the milk performance and fat content of each one of the two experimental phases respectively. Milk yield, energy- and fat-corrected milk yield, and milk chemical composition did not differ amongst the dietary groups.

\subsection{Blood Plasma and Milk Fatty Acid Profile}

Figure 3A depicts a discriminant plot of blood plasma fatty acid profile of the four dietary treatments (20 HF; blue, $20 \mathrm{HG}$; green, $40 \mathrm{HF}$; red, and $40 \mathrm{HG}$; pink) throughout the experimental period. The proportions of the samples that were correctly classified were $91.6 \%$. Wilks' lambda was observed at 0.034 for Function $1(p<0.001)$ and 0.264 for

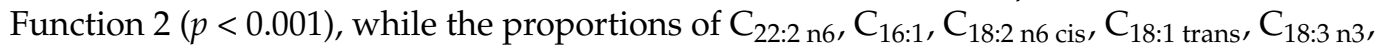
and $\mathrm{C}_{22: 6 \mathrm{n} 3}$ in blood plasma were the variables that contributed the most based on a step wise method. The four dietary treatments are clearly classified apart excepting a few minors overlapping between the same microalgae level groups. However, within Function 1 , which describes $75.9 \%$ of the model, the level of microalgae possesses the dominant role. Figure 3B depicts the second discriminant plot of milk fatty acid profile of the four dietary treatments (20 HF; blue, $20 \mathrm{HG}$; green, $40 \mathrm{HF}$; red, and $40 \mathrm{HG}$; pink) throughout the experimental period. The proportions of the samples that were correctly classified were $98.9 \%$. Wilks' lambda was observed at 0.010 for Function $1(p<0.001)$ and 0.137 for Function 2 ( $p<0.001)$, while the proportions of $\mathrm{C}_{24: 1}, \mathrm{C}_{15: 0}, \mathrm{C}_{18: 2 \mathrm{n} 6 \mathrm{cis}}, \mathrm{C}_{17: 1}, \mathrm{C}_{20: 4 \mathrm{n} 6}, \mathrm{C}_{16: 0}$, and $\mathrm{C}_{6: 0}$ in milk were the variables that contributed the most based on a step wise method. The four dietary treatments are clearly classified apart without observing any overlapping in the observations, however, within Function 1, which describes $77.8 \%$ of the model, the level of microalgae possesses the dominant role as well.

Table 4 depicts the blood fatty acid profile. Myristic acid $\left(\mathrm{C}_{14: 0}\right)$ was significantly $(p<0.001)$ increased in the blood of high microalgae-fed goats (40 HF and $40 \mathrm{HG})$; the same trend $(p<0.01)$ was found in the 42 nd experimental day compared to 21th (Table 4). These changes unveiled a significant interaction $(p<0.001)$ between microalgae level and sampling time (Table 4). Palmitic $\left(C_{16: 0}\right)$ and palmitoleic acids $\left(C_{16: 1 n-7}\right)$ were significantly $(p<0.05$ and $p<0.001$ respectively) increased in high microalgae-fed goats ( $40 \mathrm{HF}$ and 
$40 \mathrm{HG})$; while in palmitic acid, a significant interaction $(p<0.01)$ between sampling time and F:C ratio was found (Table 4$)$. Stearic acid $\left(C_{18: 0}\right)$ was significantly $(p<0.001)$ decreased in high microalgae-fed goats ( $40 \mathrm{HF}$ and $40 \mathrm{HG}$; Table 4). Vaccenic acid (VA) in blood plasma $\left(C_{18: 1 \text { trans-11 }}\right)$ tended to increase $(p=0.072)$ in high grain diets (20 HG and $40 \mathrm{HG}$ ) and significantly increased $(p<0.001)$ in high microalgae-fed goats $(40 \mathrm{HF}$ and 40 HG; Table 4$)$. Oleic acid $\left(\mathrm{C}_{18: 1}\right.$ cis-9 $)$ was significantly $(p<0.001)$ decreased in high microalgae-fed goats $(40 \mathrm{HF}$ and $40 \mathrm{HG})$; the same trend $(p<0.001)$ was found in the 42th experimental day compared to 21th (Table 4). These fluctuations resulted in significant $(p<0.05)$ interactions amongst sampling time and $\mathrm{F}: \mathrm{C}$ ratio and between all investigated factors $(p<0.05)$. Linoleic acid $\left(C_{18: 2 n-6 \text { cis }}\right)$ was significantly $(p<0.001)$ decreased in high microalgae-fed goats ( $40 \mathrm{HF}$ and $40 \mathrm{HG}$ ), while linolenic acid $\left(\mathrm{C}_{18: 3 \mathrm{n}-3}\right)$ was increased in high forage diets (20 HF and $40 \mathrm{HF}$; Table 4). Dihomo- $\gamma$-linolenic acid $\left(C_{20: 3 n-6}\right)$, Eicosatrienoic acid $\left(C_{20: 3 n 3}\right)$, docosadienoic acid $\left(C_{22: 2 n-6}\right)$, Docosapentaenoic acid $\left(C_{22: 5 n-6}\right)$, and Docosahexaenoic acid $\left(C_{22: 6 n-3}\right)$ were significantly $(p<0.001)$ increased in high microalgae-fed goats (40 HF and $40 \mathrm{HG}$; Table 4).

The mean individual fatty acids (FA), grouped FA, FA health indices, and $\Delta-9$ desaturase indices of milk are presented in Table 5. Long-chain fatty acids (LCFA) were significantly $(p<0.01)$ decreased by $41 \%$ in high $(40 \mathrm{HF}$ and $40 \mathrm{HG})$ compared to low microalgae-fed goats (Table 5). Monounsaturated fatty acids (MUFA) were significantly $(p<0.05)$ increased by $13 \%$ in high forage diets $(20 \mathrm{HF}$ and $40 \mathrm{HF})$. Polyunsaturated fatty acids (PUFA) and unsaturated fatty acids (UFA) were significantly increased by $27 \%$ $(p<0.001)$ and $6 \%(p<0.05)$, while the proportion of saturated fatty acids (SFA) were decreased $(p<0.05)$ in high ( $40 \mathrm{HF}$ and $40 \mathrm{HG}$ ) compared to low microalgae-fed goats (Table 5). The $\omega 6$ fatty acids were increased $(p<0.05)$ in high grain diets $(20 \mathrm{HG}$ and $40 \mathrm{HG}$ ), while $\omega 3$ showed a significant upsurge in high microalgae-fed goats (40 HF and $40 \mathrm{HG}$ ) resulting in changes in $\omega 6 / \omega 3$ ratio (Table 5).

Atherogenic index (AI) was significantly $(p<0.05)$ decreased $(2.37$ vs. 1.79$)$ in high grain diets (20 HG and $40 \mathrm{HG}$ ), while the opposite was found in high (40 HF and 40 HG) compared to low microalgae-fed goats (Table 5). Thrombogenic index (TI) was considerably $(p<0.001)$ decreased (1.62 vs. 1.41$)$, while the health-promoting index (HPI) of milk fatty acid profile was increased $(p<0.001)$ in high $(40 \mathrm{HF}$ and $40 \mathrm{HG})$ compared to low microalgae-fed goats (Table 5). The high inclusion level of Schizochytrium spp. was found to increase the activity of $\Delta-9$ desaturases as was indirectly indicated by the proportions of $\mathrm{C}_{16: 1} / \mathrm{C}_{16: 0}$ and $\mathrm{C}_{18: 1} / \mathrm{C}_{18: 0}$ (Table 5).

Individually, pentadecanoic acid $\left(\mathrm{C}_{15: 0}\right)$ in milk was significantly $(p<0.001)$ decreased in high grain (20 HG and $40 \mathrm{HG}$ ) compared to high forage diets (Table 5). Pentadecanoic $\left(\mathrm{C}_{15: 1}\right)$ and heptadecenoic acids $\left(\mathrm{C}_{17: 1}\right)$ were significantly $(p<0.001$ and $p<0.01$ respectively) decreased in the milk of high ( $40 \mathrm{HF}$ and $40 \mathrm{HG}$ ) compared to low microalgae-fed goats, while the $C_{17: 1}$ was also decreased $(p<0.01)$ in high grain diets (Table 5$)$. Palmitic $\left(C_{16: 0}\right)$ and palmitoleic acids $\left(C_{16: 1 ~ n-7}\right)$ were significantly $(p<0.01$ and $p<0.001$ respectively) increased in high microalgae-fed goats ( $40 \mathrm{HF}$ and $40 \mathrm{HG}$ ); while in palmitoleic acid, a significant interaction $(p<0.001)$ between sampling time and microalgae level was found (Table 5). Stearic $\left(C_{18: 0}\right)$ and oleic acids $\left(C_{18: 1 \text { cis-9 }}\right)$ were significantly $(p<0.01)$ decreased by $40 \%$ and $23 \%$ in the milk of high ( $40 \mathrm{HF}$ and $40 \mathrm{HG}$ ) compared to low microalgae-fed goats (Table 5). Total $C_{18: 1 \text { trans }}$ isomers (including VA) are significantly increased by $67 \%(p<0.05)$ in high forage diets ( $20 \mathrm{HG}$ and $40 \mathrm{HG}$ ) and by $46 \%$ in high microalgae-fed goats ( $40 \mathrm{HF}$ and $40 \mathrm{HG})$ (Table 5). Linoleic acid $\left(\mathrm{C}_{18: 2 \mathrm{n}-6 \text { cis }}\right)$ was significantly $(p<0.001)$ decreased in the milk of high microalgae-fed goats ( $40 \mathrm{HF}$ and $40 \mathrm{HG}$ ), while linolenic acid $\left(\mathrm{C}_{18: 3 \mathrm{n}-3}\right)$ was increased in high forage diets ( $20 \mathrm{HF}$ and $40 \mathrm{HF}$; Table 5). Furthermore, a significant $(p<0.05)$ interaction was unveiled between microalgae level and F:C ratio in milk linoleic

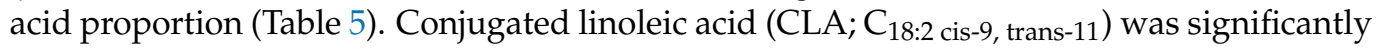
$(p<0.01)$ increased by $80 \%$ in high $(40 \mathrm{HF}$ and $40 \mathrm{HG})$ compared to low microalgae-

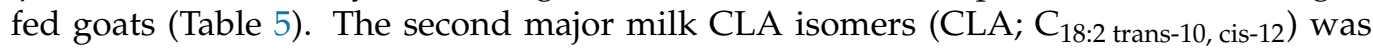
significantly $(p<0.05)$ increased by 1.4 -fold in high forage diets ( $20 \mathrm{HF}$ and $40 \mathrm{HF})$ and 
by $84 \%(p<0.05)$ in high microalgae-fed goats ( $40 \mathrm{HF}$ and $40 \mathrm{HG}$; Table 5$)$. Eicosatrienoic acid $\left(C_{20: 3 n 3}\right)$ was significantly increased $(p<0.05)$ in high forage diets $(20 \mathrm{HF}$ and $40 \mathrm{HF})$ and high microalgae-fed goats ( $p<0.001 ; 40 \mathrm{HF}$ and $40 \mathrm{HG}$ ) as well (Table 5). Additionally, the eicosatrienoic acid was observed in a higher proportion on the 42nd experimental day, while all the tested interactions were observed significant (Table 5). Arachidonic acid $\left(\mathrm{C}_{20: 4 \mathrm{n}-6}\right)$ was significantly $(p<0.001)$ increased by 2.3 -fold in high microalgae-fed goats (40 HF and $40 \mathrm{HG}$ ) and the 42nd experimental day resulting in significant interactions between the tested factors (Table 5). Eicosapentaenoic $\left(C_{20: 5 n-3}\right)$, nervonic $\left(C_{24: 1} n-9\right)$, and docosapentaenoic acid (DPA; $\left.C_{22: 5 n-6}\right)$ were significantly increased $(p<0.05)$ in high forage dietary treatments (20 HF and $40 \mathrm{HF}$ ), while DPA and nervonic acid were also increased by $71 \%(p<0.001)$ and 1.1 -fold $(p<0.001)$ in high $(40 \mathrm{HF}$ and $40 \mathrm{HG})$ compared to low microalgae fed goats (Table 5). In the case of nervonic acid, significant interactions $(p<0.01)$ were observed as well (Table 5). Docosahexaenoic acid (DHA; $C_{22: 6 n-3}$ ) was significantly $(p<0.001)$ increased by $56 \%$ in high microalgae-fed goats ( $40 \mathrm{HF}$ and $40 \mathrm{HG})$ and as well as in the 42nd experimental day resulting in significant interactions amongst the investigated factors (Table 5).

The apparent transfer efficiency of DHA from feed to milk ranged between 23 and $20 \%$ in $20 \mathrm{HF}$ and $20 \mathrm{HG}$-fed goats, respectively, while the increase of microalgae levels (40 g) considerably decreased its efficiency to $15 \%$ and $16 \%$ in $40 \mathrm{HF}$ and $40 \mathrm{HG}$-fed goats, respectively. Then again, the apparent transfer efficiency of DPA ranged between $13 \%$ and $15 \%$ in $20 \mathrm{HF}$ and $20 \mathrm{HG}$-fed goats respectively, while the increase of microalgae levels also suppressed its efficiency to $11 \%$ and $12 \%$ in $40 \mathrm{HF}$ and $40 \mathrm{HG}$ diets, respectively.

Figure 4 depicts the most significant correlations of milk fatty acids using a Pearson correlation. Eicosatrienoic acid $\left(C_{20: 3 n 3}\right)$, arachidonic acid $\left(C_{20: 4} n-6\right)$, and nervonic $\left(C_{24: 1 ~ n-9}\right)$ acid were significantly $(p<0.01)$ positively correlated with DHA content in milk $\left(R^{2}=0.511\right.$, $R^{2}=0.607$, and $R^{2}=0.800$ respectively; Figure 4$)$. The proportion of eicosatrienoic and arachidonic acid were also significantly $(p<0.01)$ positively correlated with DPA content in milk $\left(R^{2}=0.409\right.$ and $R^{2}=0.475$ respectively; Figure 4$)$.

A

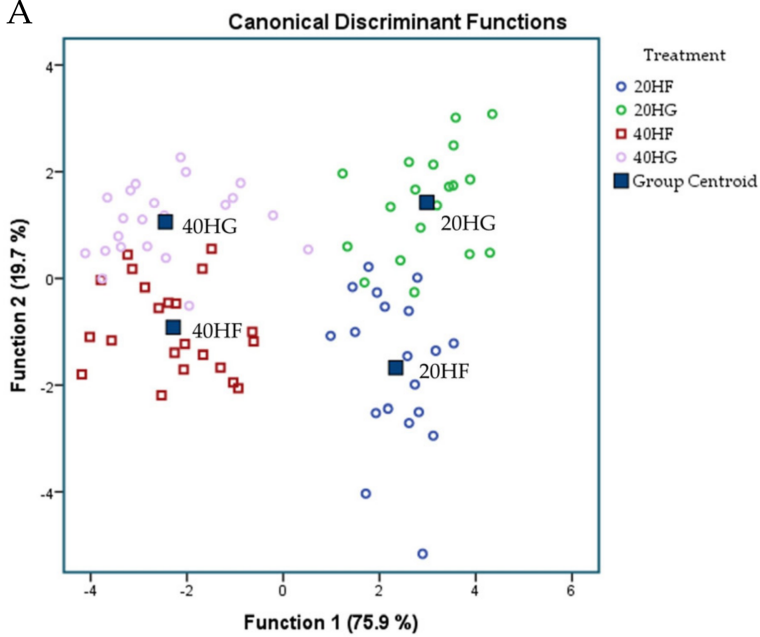

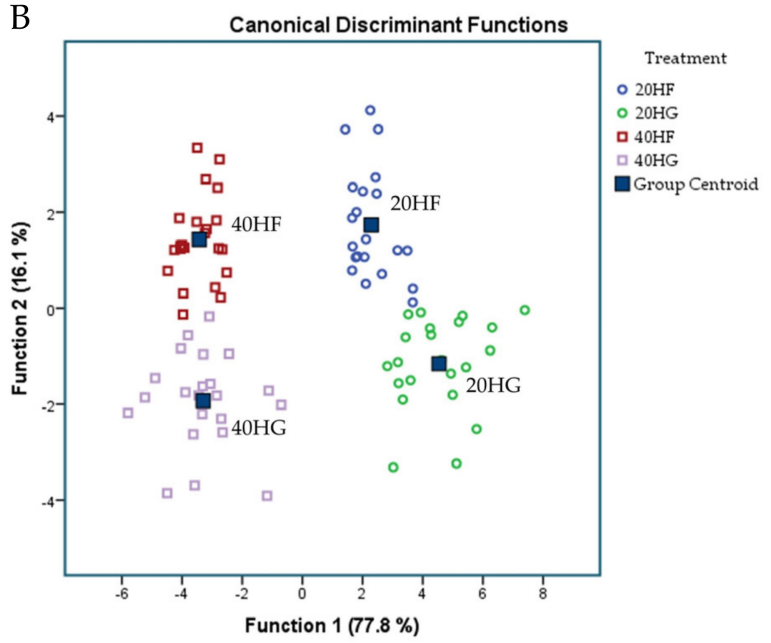

Figure 3. Discriminant plots separating (A) the four dietary treatments (20 HF; blue, 20 HG; green, 40 HF; red, and 40 HG; pink) according to pooled data of two sampling time (21st and 42nd experimental day) on the blood plasma fatty acid profile and (B) the four dietary treatments (20 HF; blue, $20 \mathrm{HG}$; green, $40 \mathrm{HF}$; red, and $40 \mathrm{HG}$; pink) according to pooled data of two sampling time (21st and 42nd experimental day) on the milk fatty acid profile. $20 \mathrm{HF}: 20 \mathrm{~g}$ Schizochytrium spp. and high forage diet (60:40); 20 HG: $20 \mathrm{~g}$ Schizochytrium spp. and high grain diet (40:60); $40 \mathrm{HF}: 40 \mathrm{~g}$ Schizochytrium spp. and high forage diet (60:40); $40 \mathrm{HG}$ : $40 \mathrm{~g}$ Schizochytrium spp. and high grain diet (40:60). 

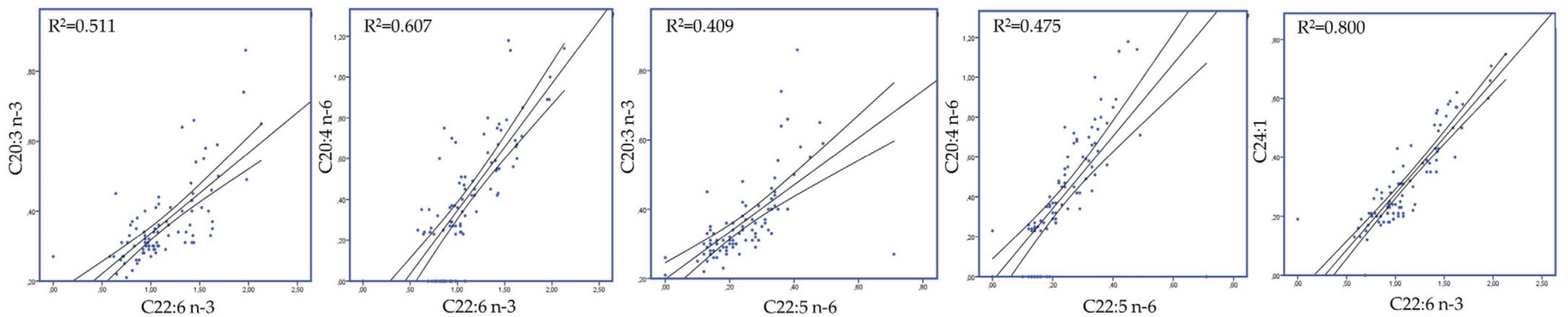

Figure 4. Pearson correlation of milk fatty acids of goats in four dietary treatments.

Table 4. The mean individual fatty acids (FA) (\% of total FA) in the blood plasma of goats fed diets (20 HF, $20 \mathrm{HG}, 40 \mathrm{HF}$, and $40 \mathrm{HG}$ ) with different levels of Schizochytrium spp. (20 g and $40 \mathrm{~g} / \mathrm{goat} /$ day) and two different forage to concentrate ratios (60:40 and 40:60) throughout the experimental period (21st and 42nd experimental days).

\begin{tabular}{|c|c|c|c|c|c|c|c|c|c|c|c|c|c|c|c|c|}
\hline & \multicolumn{6}{|c|}{ Dietary Treatment (D) } & \multirow{2}{*}{\multicolumn{3}{|c|}{$\begin{array}{c}\text { Sampling Time (S) } \\
\text { Sampling Day }\end{array}$}} & \multicolumn{7}{|c|}{ Effect } \\
\hline & \multicolumn{3}{|c|}{ Forage/Concentrate } & \multicolumn{3}{|c|}{ Algae Level } & & & & \multicolumn{3}{|c|}{ Effect } & \multicolumn{4}{|c|}{ Interaction Effect } \\
\hline & $60 / 40$ & $40 / 60$ & SEM $^{\mathrm{a}}$ & $20 \mathrm{~g}$ & $40 \mathrm{~g}$ & SEM $^{a}$ & 21 & 42 & SEM $^{a}$ & F/C & ALG & $\mathbf{S}$ & $\begin{array}{c}\mathrm{F} / \mathrm{C} \times \\
\mathbf{A}\end{array}$ & $\begin{array}{c}\mathrm{F} / \mathrm{C} \times \\
\mathrm{S}\end{array}$ & $\mathbf{A} \times \mathbf{S}$ & $\begin{array}{l}\mathbf{F} / \mathbf{C} \times \\
\mathbf{A} \times \mathbf{S}\end{array}$ \\
\hline $\mathrm{C}_{14: 0}$ & 0.432 & 0.460 & 0.033 & $0.292^{\mathrm{a}}$ & $0.599^{b}$ & 0.057 & $0.344^{\mathrm{a}}$ & $0.548^{\mathrm{b}}$ & 0.052 & NS & $* * *$ & $* *$ & NS & NS & $* * *$ & NS \\
\hline $\mathrm{C}_{16: 0}$ & 15.69 & 16.57 & 0.544 & $15.47^{\mathrm{a}}$ & $16.79^{b}$ & 0.623 & 16.26 & 16.00 & 0.558 & NS & $*$ & NS & NS & $* *$ & NS & NS \\
\hline$C_{16: 1 \mathrm{n}-7}$ & 0.423 & 0.617 & 0.072 & $0.351^{\mathrm{a}}$ & $0.689^{b}$ & 0.091 & 0.541 & 0.499 & 0.088 & $\mathrm{t}$ & $* * *$ & NS & NS & NS & NS & NS \\
\hline $\mathrm{C}_{17: 0}$ & 0.949 & 0.799 & 0.075 & 0.842 & 0.906 & 0.087 & 0.832 & 0.916 & 0.091 & NS & NS & NS & NS & NS & NS & NS \\
\hline $\mathrm{C}_{18: 0}$ & 20.25 & 15.72 & 2.039 & $22.53^{\mathrm{a}}$ & $13.45^{\mathrm{b}}$ & 2.324 & 18.68 & 17.29 & 2.199 & NS & $* * *$ & NS & NS & NS & NS & NS \\
\hline $\mathrm{C}_{18: 1 \text { trans }}$ & 1.35 & 1.01 & 0.287 & 1.34 & 1.02 & 0.320 & 1.31 & 1.06 & 0.312 & NS & NS & NS & NS & NS & NS & NS \\
\hline $\mathrm{C}_{18: 1 \text { trans-11 }}$ & 4.40 & 7.56 & 1.152 & $3.73^{\mathrm{a}}$ & $8.23^{b}$ & 1.342 & 5.42 & 6.54 & 1.224 & $\mathrm{t}$ & $* * *$ & $t$ & $*$ & NS & NS & NS \\
\hline $\mathrm{C}_{18: 1 \text { cis-9 }}$ & 8.66 & 8.71 & 0.390 & $9.19^{\mathrm{a}}$ & $8.18^{b}$ & 0.407 & $9.12^{\mathrm{a}}$ & $8.25^{\mathrm{b}}$ & 0.409 & NS & $* * *$ & $* * *$ & NS & $*$ & NS & $*$ \\
\hline $\mathrm{C}_{18: 2 \mathrm{n}-6 \text { trans }}$ & 0.527 & 0.479 & 0.070 & 0.478 & 0.528 & 0.076 & 0.533 & 0.472 & 0.082 & NS & NS & NS & $*$ & NS & $*$ & NS \\
\hline $\mathrm{C}_{18: 2 \mathrm{n}-6 \text { cis }}$ & 21.02 & 22.11 & 0.710 & $24.98^{\mathrm{a}}$ & $18.15^{\mathrm{b}}$ & 0.859 & 22.11 & 21.03 & 0.906 & NS & $* * *$ & NS & * & NS & $* *$ & $*$ \\
\hline$C_{18: 3 n-3}$ & $1.81^{\mathrm{a}}$ & $1.01^{b}$ & 0.166 & 1.44 & 1.39 & 0.178 & 1.43 & 1.39 & 0.173 & $* *$ & NS & NS & NS & NS & NS & NS \\
\hline$C_{20: 3 n-6}$ & 0.424 & 0.544 & 0.071 & $0.279^{a}$ & $0.690^{b}$ & 0.092 & $0.416^{\mathrm{a}}$ & $0.553^{\mathrm{b}}$ & 0.079 & NS & $* * *$ & $*$ & NS & NS & NS & NS \\
\hline$C_{20: 3 n-3}$ & 8.63 & 9.06 & 0.333 & $7.43^{\mathrm{a}}$ & $10.26^{b}$ & 0.414 & $8.61^{\mathrm{a}}$ & $9.09^{b}$ & 0.354 & NS & $* * *$ & $*$ & * & $* * *$ & $* *$ & NS \\
\hline$C_{22: 2 n-6}$ & 4.85 & 5.21 & 0.316 & $3.09^{\mathrm{a}}$ & $6.98^{\mathrm{b}}$ & 0.342 & $4.37^{\mathrm{a}}$ & $5.69^{b}$ & 0.322 & NS & $* * *$ & $* * *$ & * & * & NS & NS \\
\hline$C_{22: 5 n-6}$ & 1.36 & 1.50 & 0.094 & $0.922^{\mathrm{a}}$ & $1.94^{b}$ & 0.130 & $1.29^{a}$ & $1.57^{\mathrm{b}}$ & 0.128 & NS & $* * *$ & $*$ & NS & NS & NS & NS \\
\hline$C_{22: 6 n-3}$ & 9.06 & 8.47 & 0.260 & $7.60^{\mathrm{a}}$ & $9.93^{b}$ & 0.317 & 8.61 & 8.92 & 0.296 & NS & $* * *$ & NS & NS & NS & $* *$ & $* *$ \\
\hline
\end{tabular}

Means with different superscript letters $(a, b)$ between forage to concentrate ratio, algae levels and sampling time differ significantly;

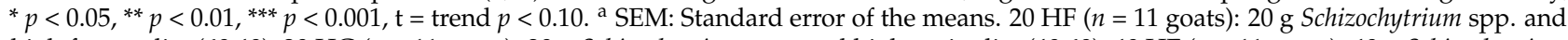
high forage diet (60:40); $20 \mathrm{HG}$ ( $n=11$ goats): $20 \mathrm{~g}$ Schizochytrium spp. and high grain diet (40:60); $40 \mathrm{HF}$ ( $n=11$ goats): $40 \mathrm{~g}$ Schizochytrium spp. and high forage diet (60:40); $40 \mathrm{HG}(n=11$ goats): $40 \mathrm{~g}$ Schizochytrium spp. and high grain diet (40:60).

Table 5. The mean individual fatty acids (FA) (\% of total FA), grouped FA, FA health indices, and $\Delta-9$ desaturase indices in the milk of goats fed diets (20 HF, $20 \mathrm{HG}, 40 \mathrm{HF}$, and $40 \mathrm{HG}$ ) with different levels of Schizochytrium spp. (20 g and $40 \mathrm{~g} / \mathrm{goat} /$ day) and two different forage to concentrate ratios (60:40 and 40:60) throughout the experimental period (21st and 42nd experimental days).

\begin{tabular}{|c|c|c|c|c|c|c|c|c|c|c|c|c|c|c|c|c|}
\hline & \multicolumn{6}{|c|}{ Dietary Treatment (D) } & \multirow{2}{*}{\multicolumn{3}{|c|}{$\begin{array}{c}\text { Sampling Time (S) } \\
\text { Sampling Day }\end{array}$}} & \multicolumn{7}{|c|}{ Effect } \\
\hline & \multicolumn{3}{|c|}{ Forage/Concentrate } & \multicolumn{3}{|c|}{ Algae Level } & & & & \multicolumn{3}{|c|}{ Effect } & \multicolumn{4}{|c|}{ Interaction Effect } \\
\hline & $60 / 40$ & $40 / 60$ & SEM $^{\mathrm{a}}$ & $20 \mathrm{~g}$ & $40 \mathrm{~g}$ & SEM $^{\mathrm{a}}$ & 21 & 42 & SEM $^{a}$ & $\mathrm{~F} / \mathrm{C}$ & ALG & $\mathrm{S}$ & $\begin{array}{c}\text { F/C } \times \\
\mathbf{A}\end{array}$ & $\begin{array}{l}\text { F/C } \times \\
\mathrm{S}\end{array}$ & $\underset{S}{A} \times$ & $\begin{array}{l}\mathrm{F} / \mathrm{C} \times \\
\mathrm{A} \times \mathbf{S}\end{array}$ \\
\hline $\mathrm{C}_{4: 0}$ & 2.83 & 2.73 & 0.094 & 2.79 & 2.76 & 0.101 & 2.75 & 2.80 & 0.106 & NS & NS & NS & NS & NS & NS & NS \\
\hline $\mathrm{C}_{6: 0}$ & 3.25 & 3.58 & 0.268 & 3.21 & 3.63 & 0.291 & 3.55 & 3.28 & 0.300 & NS & NS & NS & NS & NS & NS & NS \\
\hline $\mathrm{C}_{8: 0}$ & 3.75 & 3.84 & 0.135 & 3.77 & 3.82 & 0.148 & 3.82 & 3.78 & 0.140 & NS & NS & NS & NS & $*$ & NS & NS \\
\hline $\mathrm{C}_{10: 0}$ & 11.71 & 11.77 & 0.367 & 11.73 & 11.75 & 0.445 & $12.04^{\mathrm{a}}$ & $11.44^{\mathrm{b}}$ & 0.393 & NS & NS & $* *$ & NS & NS & NS & NS \\
\hline $\mathrm{C}_{11: 0}$ & 0.171 & 0.108 & 0.025 & 0.152 & 0.128 & 0.027 & 0.146 & 0.133 & 0.026 & NS & NS & NS & NS & NS & $*$ & NS \\
\hline $\mathrm{C}_{12: 0}$ & 4.64 & 4.56 & 0.250 & 4.65 & 4.54 & 0.289 & 4.78 & 4.41 & 0.259 & NS & NS & $* * *$ & NS & NS & NS & NS \\
\hline $\mathrm{C}_{13: 0}$ & 0.029 & 0.014 & 0.011 & $0.030^{\mathrm{a}}$ & $0.014^{b}$ & 0.012 & 0.026 & 0.018 & 0.013 & NS & $*$ & NS & $*$ & NS & NS & NS \\
\hline $\mathrm{C}_{14: 0}$ & 10.26 & 9.67 & 0.304 & 9.97 & 9.95 & 0.335 & 10.08 & 9.85 & 0.318 & NS & NS & NS & NS & NS & NS & NS \\
\hline $\mathrm{C}_{14: 1}$ & 0.304 & 0.275 & 0.015 & 0.293 & 0.287 & 0.017 & $0.304^{\mathrm{a}}$ & $0.277^{b}$ & 0.017 & NS & NS & $*$ & NS & NS & NS & NS \\
\hline $\mathrm{C}_{15: 0}$ & $0.969^{a}$ & $0.767^{b}$ & 0.037 & 0.853 & 0.883 & 0.041 & $0.888^{\mathrm{a}}$ & $0.848^{b}$ & 0.037 & $* * *$ & NS & $* * *$ & NS & NS & $*$ & NS \\
\hline $\mathrm{C}_{15: 1}$ & 0.227 & 0.208 & 0.022 & $0.257^{\mathrm{a}}$ & $0.178^{b}$ & 0.026 & $0.232^{\mathrm{a}}$ & $0.203^{b}$ & 0.024 & NS & $* * *$ & $*$ & NS & NS & NS & NS \\
\hline $\mathrm{C}_{16: 0}$ & 29.19 & 27.99 & 0.670 & $27.89^{a}$ & $29.29^{b}$ & 0.730 & 28.57 & 28.61 & 0.693 & NS & $* *$ & NS & NS & NS & NS & NS \\
\hline$C_{16: 1 \mathrm{n}-7}$ & 0.497 & 0.455 & 0.023 & $0.405^{\mathrm{a}}$ & $0.547^{\mathrm{b}}$ & 0.028 & $0.403^{\mathrm{a}}$ & $0.549^{b}$ & 0.029 & NS & $* * *$ & $* * *$ & NS & NS & $* * *$ & NS \\
\hline $\mathrm{C}_{17: 1}$ & $0.097^{\mathrm{a}}$ & $0.028^{\mathrm{b}}$ & 0.013 & $0.090^{\mathrm{a}}$ & $0.034^{\mathrm{b}}$ & 0.018 & $0.078^{\mathrm{a}}$ & $0.046^{b}$ & 0.015 & $* *$ & $* *$ & * & NS & NS & NS & NS \\
\hline $\mathrm{C}_{18: 0}$ & 7.07 & 5.67 & 0.912 & $7.98^{a}$ & $4.76^{\mathrm{b}}$ & 1.100 & 6.33 & 6.41 & 0.952 & NS & $* *$ & NS & NS & NS & NS & NS \\
\hline $\mathrm{C}_{18: 1 \text { trans }}$ & $5.92^{\mathrm{a}}$ & $9.94^{\mathrm{b}}$ & 1.189 & $6.45^{\mathrm{a}}$ & $9.42^{b}$ & 1.364 & 7.66 & 8.20 & 1.219 & $*$ & $* *$ & NS & NS & NS & $*$ & NS \\
\hline $\mathrm{C}_{18: 1 \text { cis-9 }}$ & 12.52 & 11.36 & 0.747 & $13.48^{\mathrm{a}}$ & $10.40^{\mathrm{b}}$ & 0.931 & 11.86 & 12.03 & 0.784 & NS & $* *$ & NS & NS & NS & NS & NS \\
\hline
\end{tabular}


Table 5. Cont.

\begin{tabular}{|c|c|c|c|c|c|c|c|c|c|c|c|c|c|c|c|c|}
\hline & \multicolumn{6}{|c|}{ Dietary Treatment (D) } & \multirow{2}{*}{\multicolumn{3}{|c|}{$\begin{array}{c}\text { Sampling Time (S) } \\
\text { Sampling Day }\end{array}$}} & \multicolumn{7}{|c|}{ Effect } \\
\hline & \multicolumn{3}{|c|}{ Forage/Concentrate } & \multicolumn{3}{|c|}{ Algae Level } & & & & \multicolumn{3}{|c|}{ Effect } & \multicolumn{4}{|c|}{ Interaction Effect } \\
\hline & $60 / 40$ & $40 / 60$ & SEM $^{a}$ & $20 \mathrm{~g}$ & $40 \mathrm{~g}$ & SEM $^{a}$ & 21 & 42 & SEM $^{a}$ & $\mathrm{~F} / \mathrm{C}$ & ALG & $\mathrm{S}$ & $\begin{array}{c}\mathrm{F} / \mathrm{C} \times \\
\mathrm{A}\end{array}$ & $\begin{array}{c}\mathrm{F} / \mathrm{C} \times \\
\mathrm{S}\end{array}$ & $\underset{\mathrm{S}}{\mathrm{A} \times}$ & $\begin{array}{l}\mathbf{F} / \mathbf{C} \times \\
\mathbf{A} \times \mathbf{S}\end{array}$ \\
\hline$C_{18: 2 n-6 \text { trans }}$ & 0.410 & 0.371 & 0.031 & 0.407 & 0.375 & 0.036 & 0.400 & 0.382 & 0.032 & NS & NS & NS & NS & NS & NS & $* * *$ \\
\hline$C_{18: 2 \mathrm{n}-6 \text { cis }}$ & 2.03 & 2.24 & 0.088 & $2.39^{a}$ & $1.88^{b}$ & 0.101 & 2.080 & 2.193 & 0.109 & NS & $* * *$ & NS & $*$ & NS & NS & NS \\
\hline $\mathrm{C}_{18: 3 \mathrm{n}-3}$ & $0.443^{a}$ & $0.250^{b}$ & 0.034 & 0.331 & 0.361 & 0.039 & 0.347 & 0.346 & 0.035 & $* * *$ & NS & NS & NS & NS & NS & NS \\
\hline $\mathrm{C}_{20: 0}$ & 0.122 & 0.109 & 0.006 & $0.124^{\mathrm{a}}$ & $0.107^{\mathrm{b}}$ & 0.008 & 0.114 & 0.116 & 0.007 & NS & $*$ & NS & NS & NS & $* *$ & NS \\
\hline $\begin{array}{l}\mathrm{C}_{18: 2 \text { cis- } 9} \\
\text { trans- } 11\end{array}$ & 1.21 & 1.26 & 0.175 & $0.879^{\text {a }}$ & $1.59^{\mathrm{b}}$ & 0.219 & 1.16 & 1.31 & 0.184 & NS & $* *$ & NS & NS & NS & NS & NS \\
\hline $\begin{array}{l}\mathrm{C}_{18: 2 \text { trans- }-10} \\
\quad \text { cis-12 }\end{array}$ & $0.037^{\mathrm{a}}$ & $0.089^{b}$ & 0.017 & $0.044^{\mathrm{a}}$ & $0.081^{b}$ & 0.021 & 0.069 & 0.057 & 0.019 & * & * & NS & NS & NS & * & NS \\
\hline $\mathrm{C}_{22: 0}$ & 0.052 & 0.029 & 0.012 & $0.059^{a}$ & $0.023^{b}$ & 0.016 & $0.052^{\mathrm{a}}$ & $0.030^{\mathrm{b}}$ & 0.013 & NS & $*$ & $*$ & NS & NS & NS & NS \\
\hline$C 2_{0: 3 n-3}$ & $0.320^{a}$ & $0.393^{b}$ & 0.021 & $0.302^{\mathrm{a}}$ & $0.410^{\mathrm{b}}$ & 0.021 & $0.339^{a}$ & $0.374^{\mathrm{b}}$ & 0.021 & * & $* * *$ & $* * *$ & $* * *$ & $* * *$ & $* * *$ & $* * *$ \\
\hline$C_{20: 4 n-6}$ & 0.380 & 0.450 & 0.036 & $0.190^{\mathrm{a}}$ & $0.641^{b}$ & 0.039 & $0.328^{a}$ & $0.502^{\mathrm{b}}$ & 0.039 & NS & $* * *$ & $* * *$ & $* *$ & NS & $* *$ & $*$ \\
\hline$C_{20: 5 n-3}$ & $0.009^{a}$ & $0.054^{b}$ & 0.013 & 0.025 & 0.038 & 0.015 & $0.043^{\mathrm{a}}$ & $0.020^{\mathrm{b}}$ & 0.014 & $*$ & NS & $*$ & NS & NS & NS & NS \\
\hline$C_{24: 1 \mathrm{n}-9}$ & $0.283^{a}$ & $0.357^{b}$ & 0.018 & $0.203^{a}$ & $0.437^{b}$ & 0.021 & $0.292^{\mathrm{a}}$ & $0.348^{\mathrm{b}}$ & 0.019 & $* *$ & $* * *$ & $* * *$ & $* *$ & $* *$ & $* * *$ & $* * *$ \\
\hline$C_{22: 5 n-6}$ & $0.215^{a}$ & $0.263^{b}$ & 0.016 & $0.176^{\mathrm{a}}$ & $0.302^{b}$ & 0.019 & $0.213^{\mathrm{a}}$ & $0.265^{b}$ & 0.019 & $*$ & $* * *$ & $* *$ & NS & * & NS & NS \\
\hline$C_{22: 6 n-3}$ & 1.05 & 1.17 & 0.055 & $0.865^{\mathrm{a}}$ & $1.35^{\mathrm{b}}$ & 0.059 & $1.05^{\mathrm{a}}$ & $1.17^{\mathrm{b}}$ & 0.060 & NS & $* * *$ & $* *$ & $* * *$ & * & $* * *$ & $* *$ \\
\hline \multicolumn{17}{|c|}{ Grouped Fatty Acids } \\
\hline SCFA & 21.71 & 22.03 & 0.661 & 21.65 & 22.09 & 0.740 & $22.30^{\mathrm{a}}$ & $21.44^{\mathrm{b}}$ & 0.691 & NS & NS & $*$ & NS & NS & NS & NS \\
\hline MCFA & 45.08 & 42.99 & 0.741 & 43.39 & 44.68 & 0.881 & 44.35 & 43.73 & 0.789 & $\mathrm{t}$ & $\mathrm{t}$ & NS & NS & NS & NS & NS \\
\hline LCFA & 7.25 & 5.81 & 0.924 & $8.17^{\mathrm{a}}$ & $4.89^{b}$ & 1.116 & 6.50 & 6.56 & 0.965 & NS & $* *$ & NS & NS & NS & NS & NS \\
\hline MUFA & $19.86^{\mathrm{a}}$ & $22.63^{b}$ & 0.833 & 21.18 & 21.30 & 0.923 & $20.83^{a}$ & $21.65^{b}$ & 0.871 & $*$ & NS & $*$ & NS & NS & NS & NS \\
\hline PUFA & 5.69 & 6.17 & 0.205 & $5.21^{\mathrm{a}}$ & $6.65^{b}$ & 0.235 & $5.62^{\mathrm{a}}$ & $6.23^{\mathrm{b}}$ & 0.245 & NS & $* * *$ & $* *$ & $*$ & NS & $* *$ & $* *$ \\
\hline SFA & $74.04^{\mathrm{a}}$ & $70.83^{b}$ & 0.959 & $73.21^{\mathrm{a}}$ & $71.67^{b}$ & 1.047 & $73.15^{\mathrm{a}}$ & $71.73^{\mathrm{b}}$ & 1.029 & * & * & $*$ & NS & NS & NS & NS \\
\hline UFA & $25.55^{\mathrm{a}}$ & $28.79^{b}$ & 0.965 & $26.38^{a}$ & $27.96^{b}$ & 1.054 & $26.45^{\mathrm{a}}$ & $27.89^{b}$ & 1.035 & * & * & * & NS & NS & NS & NS \\
\hline SFA/UFA & $2.99^{\mathrm{a}}$ & $2.52^{b}$ & 0.139 & $2.84^{a}$ & $2.67^{b}$ & 0.150 & $2.84^{\mathrm{a}}$ & $2.67^{b}$ & 0.147 & * & $*$ & $*$ & * & NS & NS & NS \\
\hline$\omega 6$ & $3.07^{\mathrm{a}}$ & $3.41^{\mathrm{b}}$ & 0.113 & 3.21 & 3.28 & 0.127 & $3.09^{a}$ & $3.40^{\mathrm{b}}$ & 0.134 & $*$ & NS & $* *$ & NS & NS & NS & NS \\
\hline$\omega 3$ & 1.82 & 1.87 & 0.074 & $1.52^{\mathrm{a}}$ & $2.16^{\mathrm{b}}$ & 0.079 & $1.78^{\mathrm{a}}$ & $1.91^{\mathrm{b}}$ & 0.079 & NS & $* * *$ & $* *$ & $* * *$ & $*$ & $* * *$ & $* *$ \\
\hline$\omega 6 / \omega 3$ & 1.72 & 2.05 & 0.129 & $2.23^{a}$ & $1.54^{\mathrm{b}}$ & 0.144 & 1.79 & 1.98 & 0.144 & NS & $* * *$ & NS & * & NS & NS & NS \\
\hline \multicolumn{17}{|c|}{ Fatty Acids Health Indices } \\
\hline AI & $2.37^{\mathrm{a}}$ & $1.79^{b}$ & 0.171 & $1.41^{\mathrm{a}}$ & $2.74^{\mathrm{b}}$ & 0.188 & $1.46^{\mathrm{a}}$ & $2.69^{b}$ & 0.184 & * & $* * *$ & $* * *$ & NS & NS & $* * *$ & * \\
\hline TI & 1.55 & 1.49 & 0.032 & $1.62^{\mathrm{a}}$ & $1.41^{\mathrm{b}}$ & 0.039 & 1.52 & 1.51 & 0.034 & NS & $* * *$ & NS & $*$ & NS & $* *$ & NS \\
\hline HPI & 0.669 & 0.679 & 0.006 & $0.666^{\mathrm{a}}$ & $0.683^{\mathrm{b}}$ & 0.007 & $0.670^{\mathrm{a}}$ & $0.679^{b}$ & 0.007 & NS & $* * *$ & $*$ & NS & NS & * & NS \\
\hline \multicolumn{17}{|c|}{$\Delta_{-9}$ Desaturase Indices } \\
\hline $\mathrm{C}_{14: 1} / \mathrm{C}_{14: 0}$ & 0.030 & 0.029 & 0.002 & 0.030 & 0.029 & 0.002 & 0.030 & 0.028 & 0.002 & NS & NS & NS & NS & NS & NS & NS \\
\hline $\mathrm{C}_{16: 1} / \mathrm{C}_{16: 0}$ & 0.017 & 0.016 & 0.001 & $0.015^{\mathrm{a}}$ & $0.019^{b}$ & 0.001 & $0.014^{\mathrm{a}}$ & $0.019^{b}$ & 0.001 & NS & $* * *$ & $* * *$ & NS & NS & $* * *$ & NS \\
\hline $\mathrm{C}_{18: 1} / \mathrm{C}_{18: 0}$ & 2.29 & 2.81 & 0.250 & $2.11^{\mathrm{a}}$ & $2.99^{b}$ & 0.313 & 2.60 & 2.50 & 0.261 & NS & $* *$ & NS & NS & NS & NS & NS \\
\hline
\end{tabular}

Means with different superscript letters $(a, b)$ between forage to concentrate ratio, algae levels and sampling time differ significantly; ${ }^{*} p<0.05,{ }^{* *} p<0.01,{ }^{* * *} p<0.001, \mathrm{t}=$ trend $p<0.10{ }^{a}{ }^{*}$ SEM: Standard error of the means. $20 \mathrm{HF}$ ( $n=11$ goats): $20 \mathrm{~g}$ Schizochytrium spp. and high forage diet (60:40); $20 \mathrm{HG}(n=11$ goats): $20 \mathrm{~g}$ Schizochytrium spp. and high grain diet (40:60); $40 \mathrm{HF}(n=11 \mathrm{goats}): 40 \mathrm{~g}$ Schizochytrium spp. and high forage diet (60:40); $40 \mathrm{HG}(n=11$ goats): $40 \mathrm{~g}$ Schizochytrium spp. and high grain diet (40:60).

\subsection{Blood Plasma and Milk Oxidative Status}

Figure 5A depicts a discriminant plot of blood plasma oxidative status of the four dietary treatments (20 HF; blue, $20 \mathrm{HG}$; green, $40 \mathrm{HF}$; red, and $40 \mathrm{HG}$; pink) throughout the experimental period. The proportions of the samples that were correctly classified were $71.6 \%$. Wilks' lambda was observed at 0.178 for Function $1(p<0.001)$ and 0.676 for Function $2(p=0.012)$, while the values of total antioxidant capacity using the FRAP method and the concentration of MDA were the variables that contributed the most based on a step wise method. The observation of blood oxidative status showed significant overlap, making it hard to conclude about a dependable classification. However, the centroids showed that the $20 \mathrm{HG}$ and $20 \mathrm{HF}$ groups were placed distanced from those of $40 \mathrm{HG}$ and $40 \mathrm{HF}$. Figure 5B depicts the second discriminant plot of milk oxidative status of the four dietary treatments (20 HF; blue, $20 \mathrm{HG}$; green, $40 \mathrm{HF}$; red, and $40 \mathrm{HG}$; pink) throughout the experimental period. The proportions of the samples that were correctly classified were $52.3 \%$. Wilks' lambda was observed at 0.558 for Function $1(p<0.001)$ and 0.754 for Function $2(p=0.010)$, while the values of total antioxidant capacity using the ABTS method were the variable that contributed the most based on a step wise method. Despite the significance of the results $(p<0.05)$, the high Wilks' lambda values and the severe overlapping of observations make it complicated to distinguish and classify samples amongst the four dietary groups 

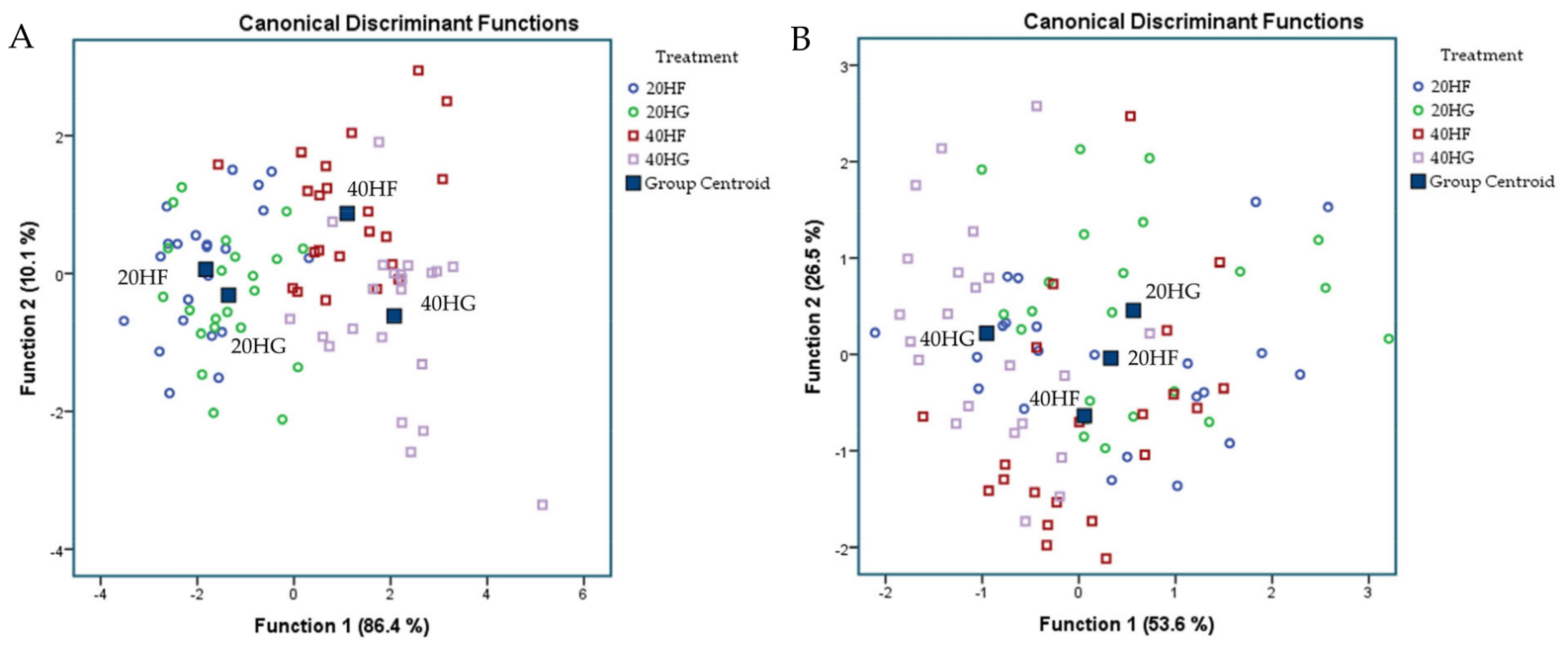

Figure 5. Discriminant plots separating (A) the four dietary treatments (20 HF; blue, 20 HG; green, 40 HF; red, and 40 HG; pink) according to pooled data of two sampling time (21st and 42nd experimental day) on the blood plasma oxidative status and (B) the four dietary treatments (20 HF; blue, $20 \mathrm{HG}$; green, $40 \mathrm{HF}$; red, and $40 \mathrm{HG}$; pink) according to pooled data of two sampling time (21st and 42nd experimental day) on the milk oxidative status. $20 \mathrm{HF}: 20 \mathrm{~g}$ Schizochytrium spp. and high forage diet (60:40); 20 HG: $20 \mathrm{~g}$ Schizochytrium spp. and high grain diet (40:60); 40 HF: 40 g. Schizochytrium spp. and high forage diet (60:40); $40 \mathrm{HG}$ : $40 \mathrm{~g}$ Schizochytrium spp. and high grain diet (40:60).

Table 6 presents the mean antioxidant enzyme activities, the total antioxidant capacity, and the oxidative status biomarkers of blood plasma and milk of goats fed with the four diets throughout the experimental period. The activity of catalase (CAT) in blood plasma was significantly $(p<0.05)$ decreased by $26 \%$ in high microalgae-fed goats (Table 6). glutathione transferase (GSTs) and superoxide dismutase (SOD) activities in blood plasma were increased ( $p<0.01$ and $p<0.001$ respectively) on the 42nd experimental day (Table 6$)$. SOD activity was also increased $(p<0.001)$ in the blood plasma of high $(40 \mathrm{HF}$ and $40 \mathrm{HG}$ ) compared to low microalgae-fed goats (Table 6). These fluctuations in SOD activity resulted in significant $(p<0.001)$ interactions amongst the investigated factors (Table 6). Total antioxidant capacity measured by ABTS assay showed a significant decrease $(p<0.01)$ on the 42nd experimental day, while total antioxidant capacity measure by FRAP method found lower in high ( $40 \mathrm{HF}$ and $40 \mathrm{HG}$ ) compared to low microalgae-fed goats (Table 6). The oxidative stress biomarkers were increased in high microalgae-fed goats indicating pro-oxidant incidence. More specifically, both protein carbonyls (CP) and malondialdehyde (MDA) concentration were increased $(p<0.001)$ in 40HF and 40 HG groups $(p<0.001)$. Additionally, MDA levels were found higher $(p<0.01)$ in high grain $(20 \mathrm{HG}$ and $40 \mathrm{HG})$ compared to high forage groups (Table 6).

Total antioxidant capacity of milk based on ABTS assay recorded lower in high microalgae-fed goats, while the $\mathrm{CP}$ was upsurged $(p<0.05)$ in the milk of goats consumed diets with a high level of grains (20 HG and $40 \mathrm{HG}$ ) compared to high forage groups (Table 6). Last but not least, both MDA and CP concentrations were reported higher on the 42nd experimental day $(p<0.01$ and $p<0.001$ respectively; Table 6). 
Table 6. Enzyme activities (Units/mL), total antioxidant capacity, and oxidative status biomarkers in blood plasma and milk of goats fed diets (20 HF, $20 \mathrm{HG}, 40 \mathrm{HF}$, and $40 \mathrm{HG}$ ) with different levels of Schizochytrium spp. (20 g and $40 \mathrm{~g} /$ goat/day) and two different forage to concentrate ratios (60:40 and 40:60) throughout the experimental period (21st and 42nd experimental days).

\begin{tabular}{|c|c|c|c|c|c|c|c|c|c|c|c|c|c|c|c|c|}
\hline & \multicolumn{6}{|c|}{ Dietary Treatment (D) } & \multirow{2}{*}{\multicolumn{3}{|c|}{$\begin{array}{c}\text { Sampling Time (S) } \\
\text { Sampling Day }\end{array}$}} & \multicolumn{7}{|c|}{ Effect } \\
\hline & \multicolumn{3}{|c|}{ Forage/Concentrate } & \multicolumn{3}{|c|}{ Algae Level } & & & & & Effect & & & teractio & Effect & \\
\hline & $60 / 40$ & $40 / 60$ & SEM $^{a}$ & $20 \mathrm{~g}$ & $40 \mathrm{~g}$ & SEM $^{a}$ & 21 & 42 & SEM $^{a}$ & F/C & ALG & $\mathbf{S}$ & $\begin{array}{c}\text { F/C } \times \\
\mathrm{A}\end{array}$ & $\begin{array}{c}\mathrm{F} / \mathrm{C} \times \\
\mathrm{S}\end{array}$ & $\mathbf{A} \times$ & $\begin{array}{l}\mathbf{F} / \mathrm{C} \times \\
\mathrm{A} \times \mathrm{S}\end{array}$ \\
\hline \multicolumn{17}{|c|}{ Blood Plasma } \\
\hline $\begin{array}{c}\text { CAT } \\
\text { units } / \mathrm{mL}\end{array}$ & 5.54 & 7.38 & 0.841 & $7.39^{\mathrm{a}}$ & $5.53^{b}$ & 0.979 & 6.01 & 6.91 & 0.937 & 0.065 & * & NS & NS & $* * *$ & NS & NS \\
\hline $\begin{array}{c}\text { GSH-Px } \\
\text { units } / m L\end{array}$ & 0.103 & 0.107 & 0.005 & 0.106 & 0.104 & 0.006 & 0.102 & 0.108 & 0.005 & NS & NS & 0.063 & NS & $* * *$ & NS & NS \\
\hline $\begin{array}{c}\text { GR } \\
\text { units } / \mathrm{mL}\end{array}$ & 0.065 & 0.059 & 0.004 & 0.061 & 0.063 & 0.005 & 0.060 & 0.065 & 0.004 & NS & NS & NS & NS & NS & NS & NS \\
\hline $\begin{array}{c}\text { GSTs } \\
\text { units } / \mathrm{mL}\end{array}$ & 0.248 & 0.266 & 0.012 & 0.246 & 0.268 & 0.016 & $0.241^{\mathrm{a}}$ & $0.273^{b}$ & 0.013 & NS & NS & $* *$ & NS & NS & NS & NS \\
\hline $\begin{array}{c}\text { SOD } \\
\text { units } / \mathrm{mL}\end{array}$ & 13.65 & 14.37 & 0.314 & $12.96^{\mathrm{a}}$ & $15.06^{\mathrm{b}}$ & 0.368 & $13.16^{\mathrm{a}}$ & $14.85^{\mathrm{b}}$ & 0.341 & NS & $* * *$ & $* * *$ & NS & NS & NS & $* * *$ \\
\hline ABTS \% & 40.88 & 40.14 & 0.492 & 39.98 & 41.04 & 0.670 & $41.41^{\mathrm{a}}$ & $39.61^{b}$ & 0.631 & NS & NS & $* *$ & $* *$ & NS & $* * *$ & NS \\
\hline FRAP $\mu \mathrm{M}$ & 0.984 & 1.11 & 0.053 & $1.14^{\mathrm{a}}$ & $0.955^{b}$ & 0.070 & 1.02 & 1.07 & 0.063 & NS & * & NS & NS & NS & NS & $* *$ \\
\hline $\begin{array}{c}\mathrm{CP} \\
\mathrm{nmol} / \mathrm{ml}\end{array}$ & 3.74 & 3.89 & 0.104 & $3.42^{\mathrm{a}}$ & $4.21^{\mathrm{b}}$ & 0.134 & $3.50^{\mathrm{a}}$ & $4.13^{\mathrm{b}}$ & 0.146 & NS & $* * *$ & $* * *$ & NS & NS & NS & NS \\
\hline $\mathrm{MDA} \mu \mathrm{M}$ & $1.33^{\mathrm{a}}$ & $1.84^{\mathrm{b}}$ & 0.119 & $1.23^{\mathrm{a}}$ & $1.94^{\mathrm{b}}$ & 0.137 & 1.57 & 1.60 & 0.127 & $* *$ & $* * *$ & NS & NS & NS & NS & NS \\
\hline \multicolumn{17}{|c|}{ Milk } \\
\hline $\begin{array}{c}\mathrm{LPO} \\
\text { units/mL }\end{array}$ & 0.804 & 0.737 & 0.042 & 0.768 & 0.772 & 0.044 & 0.765 & 0.775 & 0.046 & NS & NS & NS & NS & NS & NS & NS \\
\hline $\begin{array}{c}\text { SOD } \\
\text { units } / \mathrm{mL}\end{array}$ & 33.28 & 31.96 & 1.473 & 32.01 & 33.22 & 1.703 & $36.39^{a}$ & $28.85^{b}$ & 1.959 & NS & NS & $* * *$ & ** & NS & NS & * \\
\hline ABTS \% & 13.59 & 13.98 & 0.477 & $15.56^{\mathrm{a}}$ & $12.00^{b}$ & 0.615 & 14.27 & 13.29 & 0.676 & NS & $* * *$ & NS & * & * & $* * *$ & * \\
\hline FRAP $\mu \mathrm{M}$ & 1.44 & 1.39 & 0.062 & 1.46 & 1.37 & 0.073 & $1.65^{\mathrm{a}}$ & $1.18^{\mathrm{b}}$ & 0.078 & NS & NS & $* * *$ & * & NS & $* * *$ & $* *$ \\
\hline $\begin{array}{c}\mathrm{CP} \\
\mathrm{nmol} / \mathrm{mL}\end{array}$ & $2.87^{\mathrm{a}}$ & $3.29^{b}$ & 0.119 & 2.99 & 3.16 & 0.153 & $2.91^{\mathrm{a}}$ & $3.24^{\mathrm{b}}$ & 0.142 & * & NS & $* *$ & NS & NS & $* *$ & $* * *$ \\
\hline $\mathrm{MDA} \mu \mathrm{M}$ & 0.597 & 0.603 & 0.049 & 0.600 & 0.600 & 0.056 & $0.421^{\mathrm{a}}$ & $0.779^{b}$ & 0.053 & NS & NS & $* * *$ & $* *$ & NS & NS & * \\
\hline
\end{tabular}

Means with different superscript letters $(a, b)$ between forage to concentrate ratio, algae levels and sampling time differ significantly; ${ }^{*} p<0.05,{ }^{* *} p<0.01,{ }^{* * *} p<0.001$. ${ }^{a}$ SEM: Standard error of the means. $20 \mathrm{HF}$ ( $n=11$ goats): $20 \mathrm{~g}$ Schizochytrium spp. and high forage diet (60:40); 20 HG ( $n=11$ goats): $20 \mathrm{~g}$ Schizochytrium spp. and high grain diet (40:60); $40 \mathrm{HF}$ ( $n=11$ goats): $40 \mathrm{~g}$ Schizochytrium spp. and high forage diet (60:40); $40 \mathrm{HG}(n=11$ goats): $40 \mathrm{~g}$ Schizochytrium spp. and high grain diet (40:60).

\section{Discussion}

\subsection{High Microalgae Level Decreased Feed Intake While F:C Ratio Remained Identical}

The inclusion of high microalgae levels (40 HF and $40 \mathrm{HG}$ ) in goats' diets resulted in a decreased feed intake of concentrates and consequently lower microalgae consumption. The decrease of concentrate intake may be attributed to microalgae's fish-like flavor or the elevated fat content in the $40 \mathrm{HF}$ and $40 \mathrm{HG}$ diets (3.6\% and $4.5 \%$ respectively) that may decrease the dry matter intake (DMI) due to cholecystokinin's (hypophagic) effect on brain satiety centers [38]. On the other hand, wheat straw was decreased in high forage diets up to $50 \%$ due to its low palatability and animal resistance to long particles [39].

\subsection{The Interaction between Fat-Rich Microalgae and the F:C Ratio Did Not Affect Milk Performance}

It should be underlined here that since the two experimental phases took place at a different stage of lactation (approximately 84 vs. 140 days in milk) it was crucial to analyze the milk performance separately aiming to avoid such biases.

Although the manipulation of milk fat content by altering the $\mathrm{F}: \mathrm{C}$ ratio is considered to be a well-justified strategy, shifting from 60:40 to 40:60 did not bring on considerable changes in our study. This lies in the simultaneous microalgae supplementation in the experimental diets that robustly regulate the fat secretion compared to the $F: C$ ratio. More specifically, the marine origin fatty acids resulted in the most significant reduction of milk fat content compared to other animal and vegetable origin oils in a meta-analysis of 290 dietary treatments [14]. In this light, in our preliminary study, only the inclusion level of $40 \mathrm{~g} /$ day Schizochytrium spp. induced a severe milk fat depression in lactating goats 
compared to the normal fed [7] indicating that the PUFA supplementation level should be also considered providing design such dietary strategies.

\subsection{High Microalgae and Concentrate Levels Improved Milk Fatty Acid Profile}

Likewise, with the aforementioned hypotheses about milk fat content, the microalgae level was found to be the dominant factor of classifying blood and milk fatty acid profile compared to the F:C ratio. Palmitic acids were increased in both blood plasma and milk of goats consumed the high-microalgae level since palmitic acid appears to be a principal fatty acid in Schizochytrium spp. biomass [7]. Pendadecenoic $\left(\mathrm{C}_{15: 0}\right)$ formation is firmly dependent on rumen fermentation procedures. The reduction of $C_{15: 0}$ in high grain diets may be attributed to alterations in cellulolytic rumen microbes and their branched and odd-chain fatty acids formation [40].

Stearic acid constitutes the final product of the ruminal biohydrogenation process [41]. Reduction of stearic acid in both blood and milk of high (40 g) compared to low (20 g) microalgae-fed goats indicating that the inhibition of the biohydrogenation process depicted a dose-response. Interestingly, in our previous study, the escalated tested levels of 20, 40 , and $60 \mathrm{~g}$ of Schizochytrium spp. in dairy goats' diet did not demonstrate any tendency for dose-dependence using a moderate F:C ratio (50:50) [7]. These fluctuations may unveil the regulatory role of the $\mathrm{F}: \mathrm{C}$ ratio even though no significant alterations were observed. Further to stearic acid, total trans $C_{18: 1}$ including the vaccenic acid which constitutes the precursor of CLA and were increased in the milk of high microalgae and high grain diets as a result of a partially inhibited biohydrogenation of dietary PUFA. In compliance with our findings, an increase in trans $\mathrm{C}_{18: 1}$ isomers as a result of linolenic acid degradation products was found in high concentrate-fed ewes [42]. Similarly, a raise in the proportions of trans $C_{18: 1}$ isomers in goats' milk was observed when the animals were fed a high grain diet supplemented with different oilseeds rich in PUFA (soybeans or canola seed) [43]. The CLA concentration was also increased in the milk of high microalgae-fed goats as a result of the increased abundance of its substrate in blood and milk (vaccenic acid). These observations were found to be of high importance with the aim of the design and implement sustainable and vegetable-friendly strategies to enrich dairy products with beneficial bio-lipids for consumer health. However, the reduction of stearic acid in the blood of high microalgae-fed goats due to the lower hydrogenation degree of PUFA decreased the availability of stearic acid in the mammary gland resulted in the suppression of the de novo synthesis of oleic acid through the activity of $\Delta 9$ desaturase [44].

The second most abundant CLA isomer in milk $\left(\mathrm{C}_{18: 2} \mathrm{t} 10, \mathrm{c} 12\right)$ which has been related to the regulation of milk fat synthesis was increased in the milk of high microalgae-fed goats and high-grains diets as a result of a lower biohydrogenation activity of linoleic acid and its isomers within the rumen. In agreement with our findings, Thanh and Suksombat [45], observed higher levels of $\mathrm{C}_{18: 2} \mathrm{t} 10, \mathrm{c} 12$ in bovine milk of cows fed with high concentrate and PUFA-rich oilseeds diet. The concentration of both DPA and DHA fatty acids in blood and milk were found higher in high Schizochytrium spp. diets due to the elevated dietary intake. However, it is worth mentioning that their concentrations were recorded folds higher in the blood than that in the milk fat indicating their limited transfer efficiency as has been already reported $[7,46]$. This limitation in their transfer efficiency from feed to milk could be not only attributed to the biohydrogenation of PUFA within the rumen but also to the preference of these fatty acids to be incorporated into phospholipids and cholesteryl esters instead of triglycerides. The aforementioned preference makes these fatty acids unavailable for absorption by the mammary gland through lipoprotein lipase (LPL) compromising their efficiency [47].

The upsurge of docosadienoic acid $\left(\mathrm{C}_{22: 2 \mathrm{n}-6}\right)$ in the blood of high microalgae-fed goats appears to be a well-established observation under DHA supplementation due to the biohydrogenation activity of Butyrivibrio proteoclasticus [48]. Eicosatrienoic acid $\left(\mathrm{C}_{20: 3 \mathrm{n}-3}\right)$, arachidonic acid $\left(C_{20: 4} n-6\right)$, and nervonic $\left(C_{24: 1 n-9}\right)$ were significantly increased in the milk of high-algae fed goats. The positive response of these fatty acids to dietary the 
Schizochytrium spp. triggered our interest since their dietary intake remained identical between treatments (there are not presented in Schizochytrium spp. biomass) while there is no known mechanism of their synthesis within the mammary gland. However, their positive correlation with DPA and DHA indicating that the aforementioned fatty acids have been formed as degradation products of DPA and DHA within the rumen. Although the length of carbon chain and abundance of double bonds are degraded during the PUFA degradation within the rumen, there is a high consistency regarding the location of the remaining double bonds. Thus, it is plausible to assume that eicosatrienoic acid constitutes the degradation product of DHA, while arachidonic acid has been formed by DPA. Interestingly, the formation of arachidonic acid in the milk of algae-fed ruminants has been reported previously as well $[49,50]$.

The majority of medium-chain fatty acids (MCFA) with the principal the myristic and palmitic acid are de novo synthesized in the mammary gland. MCFA decline in high grain diets may be attributed to the inhibitory signaling of specific isomers in the lipogenic activity within the mammary gland [51]. More specifically, the proportion of $\mathrm{C}_{18: 2} \mathrm{t} 10, \mathrm{c} 12$, and $\mathrm{C}_{18: 1} \mathrm{t} 10$ which are increased in high-grain diets exert antilipogenic properties in the mammary gland [52].

From a human health point of view, the milk of high- compared to low- microalgaefed goats portrayed an improved health-promoting and thrombogenic index, while the opposite pattern was found regarding the atherogenic index. It should be pointed out that the atherogenic index depicts a few limitations, hence the milk fatty acid profile should be holistically evaluated aiming to generate dependable and reliable results. More specifically, since the atherogenic index (AI) is strongly depended on MUFA and consequently on the principal milk MUFA e.g., oleic acid, the suppression of oleic acid as was explained above adversely affects AI. Taking into consideration the aforementioned, the combination of high microalgae (40) and grain diet (60:40) performed with the healthier milk composition from the human health point of view by enriching milk fat with DHA, DPA, nervonic acid, and altering the $\omega 6 / \omega 3$ ratio toward a beneficial direction. DHA and DPA contribute to various aspects of human wellbeing, from the heart and vascular health to brain development and lifelong brain function. Indeed, these fatty acids participate in diverse processes including cell membrane structure, eicosanoid metabolism, gene transcription, and resolution of inflammation [53]. Additionally, nervonic acid is the core component of neural cells of the brain and neural tissue, which benefits brain health through improving the biosynthesis and maintenance of nerve cell myelin and also enhances neurodevelopment in premature infants. Nervonic acid can repair the damaged brain nerve pathways and promote the regeneration of nerve cells, which can be effective in the treatment of schizophrenia, psychosis, peroxisomal disorders, diabetes, alcoholism, and other conditions [54]. On the other hand, special attention should be given to arachidonic acid (ARA) enhancement since a few preliminary pieces of evidence are suggesting that ARA supplementation could increase platelet aggregation resulting in thrombotic incidences or upregulate a pro-inflammatory response through eicosanoid formation [55].

In agreement with our preliminary results [7], the upsurge of DPA and DHA intake decreases their apparent transfer efficiency from feed to milk. More specifically, the increase of microalgae levels from 20 to $40 \mathrm{~g}$ /day were negatively correlated with DPA and DHA transfer efficiency. On contrary, no differences were observed between F:C ratios. However, in this study considerably higher transfer efficiency was observed for DHA compared to our previous study and other reports $[7,56]$. More specifically, the apparent transfer efficiency of DHA was ranged between $23 \%$ to $20 \%$ in $20 \mathrm{HF}$ and $20 \mathrm{HG}$ diets respectively, while the increase of microalgae levels considerably decreased its efficiency to $15 \%$ and $16 \%$ in $40 \mathrm{HF}$ and $40 \mathrm{HG}$ diets respectively. With the exception of Keady et al. [57] who reported transfer efficiency values as high as $61 \%$ for EPA and $19-35 \%$ for DHA, it is generally thought that the transfer efficiency to the milk of EPA and DHA from fish oil added to the diet is rather low [58]. On the other hand, the apparent transfer efficiency of DPA was ranged between $13 \%$ to $15 \%$ in $20 \mathrm{HF}$ and $20 \mathrm{HG}$ diets respectively, while the 
increase of algae levels suppressed its efficiency to $11 \%$ and $12 \%$ in $40 \mathrm{HF}$ and $40 \mathrm{HG}$ diets respectively which come into agreement with our previous observations [7]. Discrepancies in DHA transfer efficiency between our experiments may be attributed to the lactation stage (from early to mid-lactation vs. mid to late-lactation), milk performance (higher milk yield in the present study), and experimental duration [58]. More specifically, the lower transfer efficiency of our preliminary study maybe lies in a bettered adaptation of the rumen microbiome during the 74 experimental days compared to 56 (14 as adaptation and 42 the main experimental period) of each experimental trial of the present study. The potential adaptation of rumen microbiota to Schizochytrium spp. inclusion may result in higher degradation of DPA and DHA during a longer interval experiment. However, considering the rumen microbiome of Schizochytrium-fed goats of our previous study, there was observed a significant alteration of the whole investigated species after the 20th experimental day in both species floated in the liquid or adhered to feed particles while no considerable changes were revealed between 40th and 60th day $[10,11]$. Nevertheless, the investigation of the genomic footprint of the ruminal microbial communities is not always corresponded to the microbes' biochemical activity and metabolism and consequently their enzymatic potential [59]. Without ruling out the potential involvement of supplementation interval on DPA and DHA transfer efficiency, Wang et al. [60] reported that cows' rumen microorganism activity is enhanced during the lactation stage resulting in a higher concentration of biohydrogenation intermediates. Thus, it could be assumed that the higher transfer efficiency of DHA in this study may lie in the earlier lactation stage.

\subsection{The Oxidative Status Subverted the State of Affairs}

PUFA appears to be prone to autoxidation and photooxidation [61]. Thus, their inclusion in animals' diets conceals severe challenges regarding organism's oxidative status. Whereas, specific saturated fatty acids such as palmitic acid could trigger cell defended mechanisms inducing a cascade of pro-oxidant incidence as well [62]. Both endogenous and exogenous mechanisms stand by cell viability by neutralizing the reactive oxygen species (ROS) [63]. In this context, the increase of SOD activity in the blood of high algaefed goats could indicate the organism's response to oxidative imbalances. More specifically, it has been reported that the supplementation of human diets with $\omega 3$ PUFA [64], or the inclusion of palmitic acid in rat diets [65] promoting the formation of superoxide anion $\left(\mathrm{O}_{2}{ }^{\bullet-}\right)$, through the mitochondria respiratory. The increased concentration of $\mathrm{O}_{2}{ }^{\bullet-}$ may cause an increase in SOD activity aiming to neutralize it. Another important generator of the superoxide anion is the NADPH oxidase (NOX) [66]. In our previous study, the escalated levels of Schizochytrium spp. in goats' diet increased the activity of plasma NOX in a dose-depended manner [16].

On the other hand, the high algae level in goats' diet decreased the activity of CAT in blood. It could be hypothesized that the increased levels of superoxide anion combined with the upsurge activity of SOD resulted in the formation of hydrogen peroxide $\left(\mathrm{H}_{2} \mathrm{O}_{2}\right)$. The formed hydrogen peroxide can cause an increase in the concentration of hydroxyl radical $\left(\mathrm{OH}^{-}\right)$, as a consequence of the Fenton reaction [67] inhibiting the activity of CAT [68]. Furthermore, the F:C ratio affected the CAT activity in blood plasma as well. More specifically, the higher CAT activity in high grain diets could be lies in the higher availability of high-digestible starch sources due to grain content [69].

The rise of MDA levels which reflect the degree of lipid peroxidation could be attributed to the increased levels of PUFA in high microalgae diets [70]. The MDA is one of the main intermediates between lipid peroxidation and oxidative stress [31]. Interestingly, blood MDA was further increased in goats who consumed high grain diets compared to those fed with high forages. Blood MDA values were ranged between 1.23 and $1.94 \mu \mathrm{M}$ indicating an increased grade of lipid peroxidation compared to previous studies on goats $(0.41-1.55 \mu \mathrm{M})$ [16] and dairy sheep $(0.60-0.89 \mu \mathrm{M})$ [71]. The mechanism that underlies this observation could be related to the high starch content of rumen which may increase the lipopolysaccharides levels in their ruminal fluid, resulting in a pro-inflammatory response 
and consequently to oxidative imbalances [17]. Another hypothesis could be lying on a robust vitamin $\mathrm{E}$ and A degradation in the rumen due to higher starch diets $[18,19]$. Notably, vitamin $\mathrm{E}$ appears to have a pivotal protective role against lipid peroxidation [72,73]. Moreover, protein carbonyls could be formed either directly through ROS action on the amino acid side chain [74], or indirectly via peroxyl radicals formed by lipid peroxidation [75]. Nevertheless, protein carbonyls are formed with much rapid grade due to the detrimental action of lipid peroxidation by-products rather than the ROS action per se [76].

Despite the presence of oxidative imbalances in the goats' organism (blood) attributed both to higher microalgae level and high grains proportion, the milk's oxidative stability portrayed an improved response to experimental diets since the principal indicator of oxidative status was not affected (MDA). However, total antioxidant capacity measured by ABTS presented low values in the milk of goats fed the high microalgae diets. Further to the microalgae inclusion level, the $\mathrm{F}: \mathrm{C}$ ratio affected milk's oxidative stability as well. Milk protein carbonyls were increased in high grain compared to a high forage diet. The exact mechanism of carbonyls formation in the milk of high grain diets while in blood plasma they were remained unaffected is still unclear. The only dependable assumption that could be given is related to the higher metal $(\mathrm{Cu}, \mathrm{Zn})$ concentration of milk compared to blood [77]. More specifically, the carbonylation of amino acid side chains constitutes a process that is commonly taking place as a result of the interaction between metals and ROS [78].

\section{Conclusions}

Although the inclusion of $40 \mathrm{~g}$ Schizochytrium spp. and high grain diet (40:60) showed the healthier milk fatty acid profile without adversely affect milk performance, diet palatability was slightly compromised and goat's organism and milk oxidative balance were severely disturbed. On the other hand, the supplementation of $20 \mathrm{~g}$ Schizochytrium spp. combined with high forage diet (60:40) appears to be a well-justified strategy to enrich dairy products with essential biomolecules for human health without negative impact in its oxidative stability. The improved transfer efficiency of DHA during early lactation triggers further research to validate, such as if the farm-scale implementation should target the period of the early lactation for short intervals aiming to produce PUFA-rich dairy products with the optimum efficiency and most sustainable manner.

Supplementary Materials: The following are available online at https://www.mdpi.com/article/10 .3390 / foods10061322/s1, Table S1. Ingredients of concentrate $(\mathrm{g} / \mathrm{Kg})$ of the four diets, Table S2. Feed chemical composition (\%), Figure S1. Average body weight $(\mathrm{Kg})$ of the four groups $(20 \mathrm{HF}, 20 \mathrm{HG}$, $40 \mathrm{HF}$, and $40 \mathrm{HG})$ of goats involved in the trial, Table S3. Average body weight (Kg) of the $20 \mathrm{HF}$ and $20 \mathrm{HG}$-fed goats throughout the experimental phase, Table S4. Average body weight $(\mathrm{Kg})$ of the $40 \mathrm{HF}$ and $40 \mathrm{HG}$-fed goats throughout the experimental phase, Table S5. Spearman correlation between blood plasma fatty acids and milk.

Author Contributions: Data curation, A.M.; formal analysis, K.S.; investigation, E.T.; methodology, A.M.; project administration, E.T.; supervision, E.T.; validation, E.T. and C.K.; writing—original draft, A.M.; writing - review and editing, E.T. and C.K. All authors have read and agreed to the published version of the manuscript.

Funding: This research received no external funding.

Institutional Review Board Statement: The study was conducted according to the guidelines of the European Union Directive on the protection of animals used for scientific purposes (EU 63/2010; Council of the European Union 2010), while taking into account an extended experimental design report, the Bioethical Committee of Faculty of Animal Science (currently known as: Agricultural University of Athens Ethical Committee in Research; FEK 38/A/2-3-2018, eide.aua) approved the experimental protocol under the No. 000012/10-5-2015.

Data Availability Statement: Data are contained within the article and Supplementary Materials. 
Acknowledgments: We sincerely thank the editor and the anonymous reviewers for their valuable comments and suggestions.

Conflicts of Interest: The authors declare no conflict of interest.

\section{References}

1. Lemahieu, C.; Bruneel, C.; Termote-Verhalle, R.; Muylaert, K.; Buyse, J.; Foubert, I. Impact of feed supplementation with different omega-3 rich microalgae species on enrichment of eggs of laying hens. Food Chem. 2013, 141, 4051-4059. [CrossRef] [PubMed]

2. Nguyen, Q.V.; Malau-Aduli, B.S.; Cavalieri, J.; Malau-Aduli, A.E.O.; Nichols, P.D. Enhancing Omega-3 Long-Chain Polyunsaturated Fatty Acid Content of Dairy-Derived Foods for Human Consumption. Nutrients 2019, 11, 743. [CrossRef] [PubMed]

3. Toral, P.G.; Hervás, g.; gómez-Cortés, P.; Frutos, P.; Juárez, M.; de la Fuente, M.A. Milk fatty acid profile and dairy sheep performance in response to diet supplementation with sunflower oil plus incremental levels of marine algae. J. Dairy Sci. 2010, 93, 1655-1667. [CrossRef]

4. $\quad$ Bichi, E.; Hervás, g.; Toral, P.G.; Loor, J.J.; Frutos, P. Milk fat depression induced by dietary marine algae in dairy ewes: Persistency of milk fatty acid composition and animal performance responses. J. Dairy Sci. 2013, 96, 524-532. [CrossRef]

5. Lum, K.K.; Kim, J.; Lei, X.G. Dual potential of microalgae as a sustainable biofuel feedstock and animal feed. J. Anim. Sci. Biotechnol. 2013, 21, 53. [CrossRef] [PubMed]

6. Yaakob, Z.; Ali, E.; Zainal, A.; Mohamad, M.; Takriff, M.S. An overview: Biomolecules from microalgae for animal feed and aquaculture. J. Biol. Res. 2014, 21, 6. [CrossRef] [PubMed]

7. Mavrommatis, A.; Tsiplakou, E. The impact of the dietary supplementation level with Schizochytrium sp.; on milk chemical composition and fatty acid profile of both blood plasma and milk of goats. Small Rum. Res. 2020, 193, 106252. [CrossRef]

8. Altomonte, I.; Salari, F.; Licitra, R.; Martini, M. Use of microalgae in ruminant nutrition and implications on milk quality-A review. Livest. Sci. 2018, 214, 25-35. [CrossRef]

9. Lopes da Silva, T.; Moniz, P.; Silva, C.; Reis, A. The Dark Side of Microalgae Biotechnology: A Heterotrophic Biorefinery Platform Directed to $\omega$-3 Rich Lipid Production. Microorganisms 2019, 7, 670. [CrossRef] [PubMed]

10. Mavrommatis, A.; Skliros, D.; Simoni, M.; Righi, F.; Flemetakis, E.; Tsiplakou, E. Alterations in the Rumen Particle-Associated Microbiota of goats in Response to Dietary Supplementation Levels of Schizochytrium spp. Sustainability 2021, 13, 607. [CrossRef]

11. Mavrommatis, A.; Sotirakoglou, K.; Skliros, D.; Flemetakis, E.; Tsiplakou, E. Dose and time response of dietary supplementation with Schizochytrium sp. on the abundances of several microorganisms in the rumen liquid of dairy goats. Lives. Sci. 2021, 247. [CrossRef]

12. Angeles-Hernandez, J.C.; Vieyra Alberto, R.; Kebreab, E.; Appuhamy, J.A.D.R.N.; Dougherty, H.C.; Castelan-Ortega, O.; gonzalezRonquillo, M. Effect of forage to concentrate ratio and fat supplementation on milk composition in dairy sheep: A meta-analysis. Livest. Sci. 2020, 238, 104069. [CrossRef]

13. Sterk, A.; Johansson, B.E.; Taweel, H.Z.; Murphy, M.; van Vuuren, A.M.; Hendriks, W.H.; Dijkstra, J. Effects of forage type, forage to concentrate ratio, and crushed linseed supplementation on milk fatty acid profile in lactating dairy cows. J. Dairy Sci. 2011, 94, 6078-6091. [CrossRef] [PubMed]

14. Chilliard, Y.; Ferlay, A. Dietary lipids and forages interactions on cow and goat milk fatty acid composition and sensory properties. Reprod. Nutr. Dev. 2004, 44, 467-492. [CrossRef] [PubMed]

15. Awada, M.; Soulage, C.O.; Meynier, A.; Debard, C.; Plaisancié, P.; Benoit, B.; Picard, g.; Loizon, E.; Chauvin, M.A.; Estienne, M.; et al. Dietary oxidized n-3 PUFA induce oxidative stress and inflammation: Role of intestinal absorption of 4-HHE and reactivity in intestinal cells. J. Lipid Res. 2012, 53, 2069-2080. [CrossRef]

16. Mavrommatis, A.; Chronopoulou, g.; Sotirakoglou, K.; Labrou, N.; Zervas, g.; Tsiplakou, E. The impact of the dietary supplementation level with Schizochytrium sp, on the oxidative capacity of both goats' organism and milk. Livest. Sci. 2018, 218, 37-43. [CrossRef]

17. Ma, N.; Abaker, J.A.; Bilal, M.S.; Dai, H.; Shen, X. Sodium butyrate improves antioxidant stability in sub-acute ruminal acidosis in dairy goats. BMC Vet. Res. 2018, 14. [CrossRef]

18. Gabai, g.; Testoni, S.; Piccinini, R.; Marinelli, L.; Stradaioli, g. Oxidative stress in primiparous cows in relation to dietary starch and the progress of lactation. Anim. Sci. 2004, 79, 99-108. [CrossRef]

19. Rode, L.M.; McAllister, T.A.; Cheng, K.J. Microbial degradation of vitamin A in rumen fluid from steers fed concentrate hay or straw diets. Can. J. Anim. Sci. 1990, 70, 227-233. [CrossRef]

20. Tsiplakou, E.; Mavrommatis, A.; Skliros, D.; Sotirakoglou, K.; Flemetakis, E.; Zervas, g. The effects of dietary supplementation with rumen-protected amino acids on the expression of several genes involved in the immune system of dairy sheep. J. Anim. Physiol. Anim. Nutr. 2018, 102, 1437-1449. [CrossRef]

21. Cannas, A.; Tedeschi, L.O.; Fox, D.G.; Pell, A.N.; Van Soest, P.J. A mechanistic model for predicting the nutrient requirements and feed biological values for sheep. J. Anim. Sci. 2004, 82, 149-169. [CrossRef] [PubMed]

22. O'Fallon, J.V.; Busboom, J.R.; Nelson, M.L.; gaskins, C.T. A direct method for fatty acid methyl ester synthesis: Application to wet meat tissues, oils, and feedstuffs. J Anim Sci. 2007, 85, 1511-1521. [CrossRef] [PubMed]

23. Various groups of Experts. DF: Bulletin of the IDF No. 285/1993-Reference Materials and Interlaboratory Collaborative Studies (Third Series); The International Dairy Federation: Brussels, Belgium, 1993; ISSN 0250-5118. 
24. The Royal Society of Chemistry. British Standards Institution. Available online: https://pubs.rsc.org/en/Content/ ArticleLanding/1952/AN/an952770546a\#!divAbstract (accessed on 15 April 2021).

25. Bondia-Pons, I.; Castellote, A.I.; López-Sabater, M.C. Comparison of conventional and fast gas chromatography in human plasma fatty acid determination. J. Chromatogr. Analyt. Technol. Biomed. Life Sci. 2004, 809, 339-344. [CrossRef]

26. Tsiplakou, E.; Chadio, S.; Zervas, g. The effect of long term under- and over-feeding of sheep on milk and plasma fatty acid profiles and on insulin and leptin concentrations. J. Dairy Res. 2012, 79, 192-200. [CrossRef] [PubMed]

27. Nourooz-Zadeh, J.; Appelqvist, L.A. Cholesterol oxides in Swedish foods and ingredients: Milk powder products. J. Food Sci. 1998, 53, 74-82. [CrossRef]

28. Tsiplakou, E.; Mountzouris, K.C.; Zervas, g. Concentration of conjugated linoleic acid in grazing sheep and goat milk fat. Livest. Sci. 2006, 103, 74-84. [CrossRef]

29. Tsiplakou, E.; Mitsiopoulou, C.; Mavrommatis, A.; Karaiskou, C.; Chronopoulou, E.G.; Mavridis, g.; Sotirakoglou, K.; Labrou, N.E.; Zervas, g. Effect of under- and overfeeding on sheep and goat milk and plasma enzymes activities related to oxidation. J. Anim. Physiol. Anim. Nutr. 2018, 102, 288-298. [CrossRef]

30. Paglia, D.E.; Valentine, W.N. Studies on the quantitative and qualitative characterization of erythrocyte glutathione peroxidase. J. Lab. Clin. Med. 1967, 70, 158-169.

31. Nielsen, F.; Mikkelsen, B.B.; Nielsen, J.B.; Andersen, H.R.; grand-Jean, P. Plasma malondialdehyde as bio-marker for oxidative stress: Reference interval and effects of life-style factors. Clin. Chem. 1997, 43, 1209-1214. [CrossRef]

32. Mavrommatis, A.; Mitsiopoulou, C.; Christodoulou, C.; Karabinas, D.; Nenov, V.; Zervas, g.; Tsiplakou, E. Dietary Supplementation of a Live Yeast Product on Dairy Sheep Milk Performance, Oxidative and Immune Status in Peripartum Period. J. Fungi 2020, 6, 334. [CrossRef]

33. Patsoukis, N.; Zervoudakis, g.; Panagopoulos, N.T.; georgiou, C.D.; Angelatou, F.; Matsokis, N.A. Thiol redox state (TRS) and oxidative stress in the mouse hippocampus after pentylenetetrazolinduced epileptic seizure. Neurosci. Lett. 2004, 357, 83-86. [CrossRef]

34. Pellegrini, N.; Serafini, M.; Colombi, B.; Del Rio, D.; Salvatore, S.; Bianchi, M.; Brighenti, F. Total antioxidant capacity of plant foods, beverages and oils consumed in Italy assessed by three different in vitro assays. J. Nutr. 2003, 133, 2812-2819. [CrossRef]

35. Li, P.; Huo, L.; Su, W.; Lu, R.; Deng, C.; Li, L.; He, C. Free radical scavenging capacity, antioxidant activity and phenolic content of Pouzolzia zeylanica. J. Serbian Chem. Soc. 2011, 76, 709-717. [CrossRef]

36. Benzie, I.F.; Strain, J.J. The ferric reducing ability of plasma (FRAP) as a measure of "antioxidant power": The FRAP assay. Anal. Biochem. 1996, 239, 70-76. [CrossRef]

37. Alrawashdeh, M.; Radwan, T. Wilk's lambda based on robust method. AIP Conf. Proc. 2017, 1842, 030032.

38. Allen, M.S. Effects of diet on short-term regulation of feed intake by lactating dairy cattle. J Dairy Sci. 2000, 83, 1598-1624. [CrossRef]

39. Baumont, R. Palatability and feeding behaviour in ruminants. A review. Annales Zootech. 1996, 45, 385-400. [CrossRef]

40. Liu, K.; Hao, X.; Li, Y.; Luo, g.; Zhang, Y.; Xin, H. The relationship between odd- and branched-chain fatty acids and microbial nucleic acid bases in rumen. Asian Australas. J. Anim. Sci. 2017, 30, 1590-1597. [CrossRef] [PubMed]

41. Dewanckele, L.; Toral, P.G.; Vlaeminck, B.; Fievez, V. Invited review: Role of rumen biohydrogenation intermediates and rumen microbes in diet-induced milk fat depression: An update. J. Dairy Sci. 2020, 103, 7655-7681. [CrossRef]

42. Gómez-Cortés, P.; de la Fuente, M.A.; Toral, P.G.; Frutos, P.; Juárez, M.; Hervás, g. Effects of different forage:concentrate ratios in dairy ewe diets supplemented with sunflower oil on animal performance and milk fatty acid profile. J. Dairy Sci. 2011, 94, 4578-4588. [CrossRef] [PubMed]

43. Schmidely, P.; Andrade, P.V.D. Dairy performance and milk fatty acid composition of dairy goats fed high or low concentrate diet in combination with soybeans or canola seed supplementation. S. Rum. Res. 2011, 99, 135-142. [CrossRef]

44. Toral, P.G.; Frutos, P.; Carrenño, D.; Hervaás, g. Endogenous synthesis of milk oleic acid in dairy ewes: In vivo measurement using 13 C-labeled stearic acid. J. Dairy Sci. 2017, 100, 5880-5887. [CrossRef] [PubMed]

45. Thanh, L.P.; Suksombat, W. Milk Yield, Composition, and Fatty Acid Profile in Dairy Cows Fed a High-concentrate Diet Blended with Oil Mixtures Rich in Polyunsaturated Fatty Acids. Asian Australas. J. Anim. Sci. 2015, 28, 796-806. [CrossRef] [PubMed]

46. Farina, g.; Cattaneo, D.; Lecchi, C.; Invernizzi, g.; Savoini, g.; Agazzi, A. A review on the role of EPA and DHA through goat nutrition to human health: Could they be effective both to animals and humans? J. Dairy Vet. Anim. Res. 2015, 2, 35-39. [CrossRef]

47. Lanier, S.; Suagee, J.K.; Becvar, O.; Corl, B.A. Mammary Uptake of Fatty Acids Supplied by Intravenous Triacylglycerol Infusion to Lactating Dairy Cows. Lipids 2013, 48, 469-479. [CrossRef] [PubMed]

48. Jeyanathan, J.; Escobar, M.; Wallace, R.J.; Fievez, V.; Vlaeminck, B. Biohydrogenation of 22:6n-3 by butyrivibrio proteoclasticus p18. BMC Microbiol. 2016, 16, 104. [CrossRef]

49. Barclay, W.; Abril, R.; Abril, P.; Weaver, C.; Ashford, A. Production of docosahexaenoic acid from microalgae and its benefits for use in animal feeds A.P. Simopoulos (Ed.), The Return of $\omega 3$ Fatty Acids into the Food Supply. I. Land-Based Animal Food Products and Their Health Effects. In World Review of Nutrition and Diet; Omega Tech Inc.: Karger, Basel, Switzerland, 1998; Volume 83, pp. 61-76.

50. Franklin, S.T.; Martin, K.R.; Baer, R.J.; Schingoethe, D.J.; Hippen, A.R. Dietary marine algae (Schizochytrium sp.) increases concentrations of conjugated linoleic, docosahexaenoic and trans vaccenic acids in milk of dairy cows. J. Nutr. 1999, 129, 2048-2054. [CrossRef] 
51. Mele, M.; Buccioni, A.; Petacchi, F.; Serra, A.; Banni, S.; Antongiovanni, M.; Secchiari, P. Effect of forage/concentrate ratio and soybean oil supplementation on milk yield, and composition from Sarda ewes. Anim. Res. 2006, 55, 273-285. [CrossRef]

52. Piperova, L.S.; Teter, B.B.; Bruckental, I.; Sampugna, J.; Mills, S.E.; Yurawecz, M.P.; Fritsche, J.; Ku, K.; Erdman, R.A. Mammary lipogenic enzyme activity, trans fatty acids and conjugated linoleic acids are altered in lactating dairy cows fed a milk fatdepressing diet. J. Nutr. 2000, 130, 2568-2574. [CrossRef]

53. Byelashov, O.A.; Sinclair, A.J.; Kaur, g. Dietary sources, current intakes, and nutritional role of omega-3 docosapentaenoic acid. Lipid Technol. 2015, 27, 79-82. [CrossRef]

54. Qiao, Q.; Wang, X.; Ren, H.; An, K.; Feng, Z.; Cheng, T.; Sun, Z. Oil Content and Nervonic Acid Content of Acer truncatum Seeds from 14 Regions in China. Hortic. Plant J. 2019, 5, 24-30. [CrossRef]

55. Calder, P.C.; Campoy, C.; Eilander, A.; Fleith, M.; Forsyth, S.; Larsson, P.O.; Mensink, R.P. A systematic review of the effects of increasing arachidonic acid intake on PUFA status, metabolism and health-related outcomes in humans. Br. J. Nutr. $2019,1$. [CrossRef] [PubMed]

56. Huang, g.; Zhang, Y.; Xu, Q.; Zheng, N.; Zhao, S.; Liu, K.; Qu, X.; Yu, J.; Wang, J. DHA content in milk and biohydrogenation pathway in rumen: A review. PeerJ 2020, 8, e10230. [CrossRef]

57. Keady, T.W.J.; Mayne, C.S.; Fitzpatrick, D.A. Effects of supplementation of dairy cattle with fish oil on silage intake, milk yield and milk composition. J. Dairy Res. 2000, 67, 137-153. [CrossRef]

58. Chilliard, Y.; Ferlay, A.; Doreau, M. Effect of different types of forages, animal fat or marine oils in cow's diet on milk fat secretion and composition, especially conjugated linoleic acid (CLA) and polyunsaturated fatty acids. Lives. Prod. Sci. 2001, 70, 31-48. [CrossRef]

59. Huws, S.A.; Kim, E.J.; Lee, M.R.F.; Scott, M.B.; Tweed, J.K.S.; Pinloche, E.; Scollan, N.D. As yet uncultured bacteria phylogenetically classified as Prevotella, Lachnospiraceae incertae sedis and unclassified Bacteroidales, Clostridiales and Ruminococcaceae may play a predominant role in ruminal biohydrogenation. Environ. Microbiol. 2011, 13, 1500-1512. [CrossRef] [PubMed]

60. Wang, T.; Oh, J.J.; Lim, J.N.; Hong, J.E.; Kim, J.H.; Kim, J.H.; Kang, H.S.; Choi, Y.J.; Lee, H.G. Effects of Lactation Stage and Individual Perfor-mance on Milk cis-9, trans-11 Conjugated Linoleic Acids Content in Dairy Cows. Asian Australas. J. Anim. Sci. 2013, 26, 189-194. [CrossRef] [PubMed]

61. Yin, H.; Porter, N.A. New insights regarding the autoxidation of polyunsaturated fatty acids. Antioxid. Redox Signal. 2005, 7, 170-184. [CrossRef] [PubMed]

62. Wu, K.M.; Hsu, Y.M.; Ying, M.C. High-density lipoprotein ameliorates palmitic acid-induced lipotoxicity and oxidative dysfunction in H9c2 cardiomyoblast cells via ROS suppression. Nutr. Metab. 2019, 16, 36. [CrossRef]

63. Mavrommatis, A.; giamouri, E.; Tavrizelou, S.; Zacharioudaki, M.; Danezis, g.; Simitzis, P.E.; Zoidis, E.; Tsiplakou, E.; Pappas, A.C.; georgiou, C.A.; et al. Impact of Mycotoxins on Animals' Oxidative Status. Antioxidants 2021, 10, 214. [CrossRef]

64. Đuričić, I.; Kotur-Stevuljević, J.; Miljković, M.; Kerkez, M.; Đorđević, V.; Đurašić, L.; Šobajić, S. Effect of Nutritionally Relevant Doses of Long-Chain N-3 Pufa on Lipid Status, Oxidative Stress and Inflammatory Markers in an Average Middle-Aged Serbian Population. J. Med. Biochem. 2015, 34, 304-313. [CrossRef] [PubMed]

65. Gao, Z.; Zhang, H.; Liu, J.; Lau, C.W.; Liu, P.; Chen, Z.Y.; Lee, H.K.; Tipoe, g.L.; Ho, H.M.; Yao, X.; et al. Cyclooxygenase-2dependent oxidative stress mediates palmitate-induced impairment of endothelium-dependent relaxations in mouse arteries. Biochem. Pharmacol. 2014, 91, 474-482. [CrossRef]

66. Katsuyama, M. NOX/NADPH oxidase, the superoxide-generating enzyme: Its transcriptional regulation and physiological roles. J. Pharmacol. Sci. 2010, 114, 134-146. [CrossRef] [PubMed]

67. Winterbourn, C.C. Toxicity of iron and hydrogen peroxide: The Fenton reaction. Toxicol. Lett. 1995, 82-83, 969-974. [CrossRef]

68. Pigeolet, E.; Corbisier, P.; Houbion, A.; Lambert, D.; Michiels, C.; Raes, M.; Zachary, M.D.; Remacle, J. glutathione peroxidase, superoxide dismutase, and catalase inactivation by peroxides and oxygen derived free radicals. Mech. Ageing Dev. 1990, 51, 283-297. [CrossRef]

69. Song, M.Q.; Shi, C.M.; Lin, S.M.; Chen, Y.J.; Shen, H.M.; Luo, L. Effect of starch sources on growth, hepatic glucose metabolism and antioxidant capacity in juvenile largemouth bass, Micropterus salmoides. Aquaculture 2018, 490, 355-361. [CrossRef]

70. Larsson, K.; Harrysson, H.; Havenaar, R.; Alminger, M.; Undeland, I. Formation of malondialdehyde (MDA), 4-hydroxy-2-hexenal (HHE) and 4-hydroxy-2-nonenal (HNE) in fish and fish oil during dynamic gastrointestinal in vitro digestion. Food Funct. 2016, 7 , 1176-1187. [CrossRef] [PubMed]

71. Mavrommatis, A.; Mitsiopoulou, C.; Christodoulou, C.; Kariampa, P.; Simoni, M.; Righi, F.; Tsiplakou, E. Effects of Supplementing Rumen-Protected Methionine and Lysine on Milk Performance and Oxidative Status of Dairy Ewes. Antioxidants 2021, 10, 654. [CrossRef]

72. Abdelhalim, M.A.K.; Qaid, H.A.Y.; Al-Mohy, Y.H.; ghannam, M.M. The Protective Roles of Vitamin E and $\alpha$-Lipoic Acid Against Nephrotoxicity, Lipid Peroxidation, and Inflammatory Damage Induced by gold Nanoparticles. Int. J. Nanomed. 2020, 15, 729-734. [CrossRef] [PubMed]

73. Huang, H.Y.; Appel, L.J.; Croft, K.D.; Miller, E.R.; Mori, T.A.; Puddey, I.B. Effects of vitamin C and vitamin E on in vivo lipid peroxidation: Results of a randomized controlled trial. Am. J. Clin. Nutr. 2002, 76, 549-555. [CrossRef] [PubMed]

74. Dalle-Donne, I.; Rossi, R.; giustarini, D.; Milzani, A.; Colombo, R. Protein carbonyl groups as biomarkers of oxidative stress. Clin. Chim. Acta. 2003, 329, 23-38. [CrossRef] 
75. Grimsrud, P.A.; Xie, H.; griffin, T.J.; Bernlohr, D.A. Oxidative stress and covalent modification of protein with bioactive aldehydes. J. Biol. Chem. 2008, 283, 21837-21841. [CrossRef]

76. Yuan, S.B.; Chen, D.W.; Zhang, K.Y.; Yu, B. Effects of oxidative stress on growth performance, nutrient digestibilities and activities of antioxidative enzymes of weanling pigs. Asian Australas. J. Anim. Sci. 2007, 20, 1600-1605. [CrossRef]

77. Pechova, A.; Misurova, L.; Pavlata, L.; Dvorak, R. The influence of supplementation of different forms of zinc in goats on the zinc concentration in blood plasma and milk. Biol. Trace Elem. Res. 2009, 132, 112-121. [CrossRef] [PubMed]

78. Castillo-Castañeda, P.C.; gaxiola-Robles, R.; Labrada-Martagón, V.; Acosta Vargas, B.; Méndez-Rodríguez, L.C.; Zenteno-Savín, T. Oxidative damage to proteins related to metals and antioxidant defenses in breastmilk. Nutr. Hosp. 2017, 34, 59-64. [CrossRef] [PubMed] 